\title{
Developmentally distinct in vivo effects of FSH on proliferation and apoptosis during testis maturation
}

\author{
Sarah J Meachem ${ }^{1}$, Saleela M Ruwanpura ${ }^{1}$, Jessica Ziolkowski ${ }^{2}$, \\ Jacquelyn M Ague ${ }^{3}$, Michael K Skinner ${ }^{3}$ and Kate L Loveland ${ }^{2,4}$ \\ ${ }^{1}$ Prince Henry's Institute of Medical Research, Monash Medical Centre, 246 Clayton Road, Clayton, Victoria, 3168 , Australia \\ ${ }^{2}$ Monash Institute for Medical Research, Monash University, Clayton, Victoria, 3168, Australia \\ ${ }^{3}$ Center for Reproductive Biology, School of Molecular Biosciences, Washington State University, Pullman, Washington, 99164, USA \\ ${ }^{4}$ The Australian Research Council Centre of Excellence in Biotechnology and Development \\ (Requests for offprints should be addressed to S J Meachem; Email: sarah.meachem@phimr.monash.edu.au)
}

\begin{abstract}
The critical influence of follicle stimulating hormone (FSH) on male fertility relates both to its impact on Sertoli cell proliferation in perinatal life and to its influence on the synthesis of Sertoli cell-derived products essential for germ cell survival and function in the developing adult testis. The nature and timing of this shift of germ cells to their reliance on specific Sertoli cell-derived products are not defined. Based on existing data, it is apparent that the dominant function of FSH shifts between 9 and 18 day postpartum (dpp) during the first wave of spermatogenesis from driving Sertoli cell proliferation to support germ cells. To enable comprehensive analysis of the impact of acute in vivo FSH suppression on Sertoli and germ cell development, FSH was selectively suppressed in Sprague-Dawley rats by passive immunisation for 2 days and/or 4 days prior to testis collection at 3,9 and $18 \mathrm{dpp}$. The $3 \mathrm{dpp}$ samples displayed no measurable changes, while 4 days of FSH suppression decreased Sertoli cell proliferation and numbers in $9 \mathrm{dpp}$, but not $18 \mathrm{dpp}$, animals. In contrast,
\end{abstract}

germ cell numbers were unaffected at 9 dpp but decreased at 18 dpp following FSH suppression, with a corresponding increase in germ cell apoptosis measured at $18 \mathrm{dpp}$. Sixty transcripts were measured as changed at $18 \mathrm{dpp}$ in response to 4 days of FSH suppression, as assessed using Affymetrix microarrays. Some of these are known as Sertoli cell-derived FSH-responsive genes (e.g. StAR, cathepsin L, insulin-like growth factor binding protein-3), while others encode proteins involved in cell cycle and survival regulation (e.g. cyclin D1, scavenger receptor class $B$ 1). These data demonstrate that FSH differentially affects Sertoli and germ cells in an age-dependent manner in vivo, promoting Sertoli cell mitosis at day 9, and supporting germ cell viability at day 18 . This model has enabled identification of candidate genes that contribute to the FSH-mediated pathway by which Sertoli cells support germ cells.

Journal of Endocrinology (2005) 186, 429-446

\section{Introduction}

Sperm production in the adult male requires establishment of the Sertoli cell population and initiation of the first spermatogenic wave, events that occur during foetal and early postnatal life. In the rat, Sertoli cells proliferate until around 15 days after birth, setting the full complement of Sertoli cells. Surrounded by Sertoli cells, the gonocytes multiply in the foetal testis and then enter a period of quiescence lasting a week. They resume mitosis at 3 days after birth and migrate to the basement membrane at the seminiferous cord perimeter. Once they have contacted the basement membrane they are called spermatogonia. Spermatogonia subsequently pass through three developmental phases involving mitosis, meiosis and spermiogenesis to form spermatozoa, with the germ cells completing the first wave of spermatogenesis at 43 days after birth in the rat (de Rooij 1998).

The mechanisms by which the Sertoli and germ cell populations are regulated during the first spermatogenic wave are under investigation and appear to be influenced by a complex network of interacting signals. It is known that pituitary-derived follicle stimulating hormone (FSH) exerts its effects on the developing germ cells indirectly, as only the Sertoli cells bear FSH receptors. A key role of FSH in setting the size of the Sertoli cell population in early postnatal life has been attributed to its stimulatory effect on Sertoli cell division (Orth 1984, Orth et al. 1988, Boitani et al. 1995). The response of the Sertoli cell to FSH changes during the first wave of spermatogenesis in rodents, and this influences the proliferation of Sertoli cells (Boitani et al. 1995, Meehan et al. 2000, 
Buzzard et al. 2003). Synthesis of several Sertoli cell products also changes during development, however whether some of these are regulated by FSH in vivo remains to be determined (Munsie et al. 1997, Yan et al. 2001, Fragale et al. 2001, Migrenne et al. 2003, Pellegrini et al. 2003). FSH-regulated apoptosis during the first spermatogenic wave has not been examined, however in adult rats, germ cells are lost through apoptosis (Meachem et al. 1999), rather than through reduced proliferation when FSH is manipulated (McLachlan et al. 1995). However the regulation of adult spermatogenesis cannot be assumed to be mediated in the same manner as is the first spermatogenic wave, as shifts in the expression patterns of key regulatory genes (i.e., Bcl-2 family members and stem cell factor (SCF) have been observed as Sertoli cells mature and eventually mature germ cell populations emerge (Munsie et al. 1997, Huang et al. 1992, Meehan et al. 2001).

A large number of FSH responsive genes have been identified, however in most cases, their specific contribution to Sertoli cell and germ cell viability and function is undefined. The interaction of SCF with its receptor, c-kit, is essential for germ cell progression and survival in first wave and adult spermatogenesis (Yoshinaga et al. 1991, Packer et al. 1995), and expression of SCF in Sertoli cells has been shown to be regulated by FSH in vitro and in vivo (Rossi et al. 1993, McLean et al. 2002). Expression of the transcription factor DMRT1 in Sertoli cells can be elevated by FSH in vivo (Chen \& Heckert 2001) and a role for DMRT1 in early postnatal testicular development relating to the termination of Sertoli cell proliferation has been deduced from the phenotype of DMRT -/- mice (Raymond et al. 2000). Some genes encoding apoptotic regulators in the Bcl-2 family of proteins have also been shown to be responsive to $\mathrm{FSH}$, including $\mathrm{Bcl}-\mathrm{w}$ and $\mathrm{Bok}$ (Yan et al. 2000, Suominen et al. 2001). A recent study using microarray analyses has defined 100-300 known transcripts that are regulated by FSH in cultures of Sertoli cells from 20 days post partum (dpp) rats (McLean et al. 2002). It is now timely to identify the FSH regulated genes involved in testicular development and spermatogenesis using an in vivo approach.

To more precisely understand the dynamic mechanisms by which FSH acts in immature rats, we set out to identify the cells that respond to in vivo changes in FSH levels during the first wave of spermatogenesis and to examine the functional changes in these cells. Administration of an antibody to FSH was performed to selectively suppress FSH for two or four days by immunoneutralisation. This acute FSH suppression differentially affected Sertoli and germ cell numbers during development as assessed by the, unbiased, optical disector stereological technique, corresponding with selective changes in proliferation and apoptosis in these cell types. Rat genomic microarrays enabled identification of candidate genes regulated by FSH from 14 to $18 \mathrm{dpp}$. The value of this model for interrogating the changing roles of FSH in the first wave of spermatogenesis is discussed.

\section{Material and Methods}

\section{Animals}

Male outbred Sprague-Dawley rat pups with mothers were obtained from the Monash University Central Animal House (Clayton, Australia). They were maintained at $20^{\circ} \mathrm{C}$ in a fixed $12 \mathrm{~h}$ light: $12 \mathrm{~h}$ darkness cycle with free access to food and water in accordance with the Australian Code of Practice for Care and Use of Animals for Scientific Purposes (1997, National Health and Medical Research Council, Australia). This study was approved by the Monash Medical Centre Animal Ethics Committee.

\section{Passive immunisation against FSH}

The ability of the polyclonal ovine antisera raised against rat $\mathrm{FSH}$ (FSHAb) to neutralise rat $\mathrm{FSH}$ in vitro and in vivo has been previously described (Meachem et al. 1998). The level of neutralisation of serum FSH achieved in adult rats was greater than 90\% (reaching the limit of assay detection). Rat pups were immunised with the FSHAb or with normal sheep immunoglobulin (ConAb) at a daily dose of $10 \mathrm{mg} / \mathrm{kg}$, a 5 -fold higher dose than that previously administered to adult rats. Each animal received s.c. injections 2 days prior to death at 3 days dpp, and 2 and 4 days prior to death at 9 and $18 \mathrm{dpp}$. Ten rats were injected for each data point.

\section{Tissue collection and preparation}

One $\mathrm{h}$ prior to death, each rat received 5-bromodeoxyurdine (BrdU; $50 \mathrm{mg} / \mathrm{kg}$, s.c. Sigma) to enable proliferation analysis. Rats were killed $24 \mathrm{~h}$ after the final injection of the antibody, at 3, 9 or $18 \mathrm{dpp}$, by decapitation. Trunk blood was collected and allowed to clot overnight at $4{ }^{\circ} \mathrm{C}$ prior to serum collection for hormone assays. Due to the small amounts of serum collected for day 3 and 9 dpp rats, these samples were pooled in groups of three and two animals, respectively. The testes were then excised and weighed. The right testis of each animal was snap frozen on dry ice and stored at $-75{ }^{\circ} \mathrm{C}$ for RNA preparation, while left testis was immersion-fixed with Bouin's solution for less than $5 \mathrm{~h}$ and sliced into 2-mm thick slabs orthogonal to the long axis of the testis. The testes from 9 and 18 dpp rats were divided into two, or four slices, respectively, and half of each processed into hydroxyethylmethacrylate resin (Technovit 7100; Kulzer and Co. GmBH, Friedrichsdorf, Germany) according to the manufacturer's instructions, while the other half was used for routine embedding into paraffin. The whole left testis from $3 \mathrm{dpp}$ rats was embedded in resin and paraffin in every second 
animal. Thick $(25 \mu \mathrm{m})$ resin sections were serially cut (Supercut Microtome, Reichert Jung 2050, Nossloch, Germany), stained with the Periodic acid-Schiff's reaction reagents and counterstained with Mayer's Haematoxylin for the determination of cell number. Thin $(5 \mu \mathrm{m})$ paraffin sections were placed on Superfrost Plus slides for analysis of proliferation and apoptosis.

\section{Cell number estimates using the optical disector}

The optical disector stereological method (Wreford 1995) was used to determine the total number of cell nuclei per testis. All measurements were performed using a $100 \times$ objective on an Olympus BX-50 microscope (Olympus, Tokyo, Japan). A microcator (D 8225; Heideinhain, Traunreut, Germany) that monitored scanned depth was attached to the microscope stage. The images were captured by a JVC TK-C1381 video camera coupled to a Pentium PC computer using a Screen Machine II fast multimedia video adapter (FAST, Hamburg, Germany). The software package, CASTGRID V1.60 (Olympus, Denmark, Germany), was used to generate an unbiased counting frame superimposed on video image. Fields were selected by a systematic uniform random sampling scheme as previously described (McLachlan et al. 1994, Wreford 1995) with the use of a motorized stage (Multicontrol 2000; ITK, Lahnau, Germany). The final screen magnification was 2708 -fold.

Sertoli cells were identified by their irregularly shaped nuclei, which were often positioned towards to the basement membrane and contained multiple nucleoli. Gonocytes were relatively large circular to ovoid cells with large circular nuclei, centrally located within the epithelium. Type A and B spermatogonia/preleptotene spermatocytes, leptotene/zygotene spermatocytes and pachytene spermatocytes were identified according to the characteristics described (Russell et al. 1990). Type B spermatogonia and preleptotene spermatocytes were not readily distinguishable at these stages of development and were counted as one. At least 300 Sertoli cell nuclei in total per testis were counted using the unbiased counting frame $\left(175-430 \mu^{2}\right)$ and at least 80 gonocytes, spermatogonia (type A, B spermatogonia and preletotene spermatocytes) or spermatocytes (leptotene, zygotene and pachytene spermatocytes) were counted employing a larger frame (430$\left.1923 \mu^{2}\right)$. The frame size was selected based on cell frequency at different time points; less abundant cell types were counted in a larger counting frame. No correction for shrinkage was required (Meachem et al. 1996). Slides were masked prior to each type of quantitation (cell number, proliferation and apoptosis) to facilitate unbiased counting.

\section{Proliferation analysis}

BrdU incorporation into testicular cells at 3, 9 and $18 \mathrm{dpp}$ was detected by immunohistochemistry as previously described (Schlatt et al. 1999), with minor modifications as described below (see Fig 1A). In brief, slides bearing paraffin-embedded tissue sections were deparaffinized, rehydrated, and subjected to antigen retrieval in citrate buffer $\left(0 \cdot 1 \mathrm{M}, \mathrm{pH} 6 ; 90-95{ }^{\circ} \mathrm{C}\right.$ for $10 \mathrm{~min}$ then room temperature for $20 \mathrm{~min}$ ). Sections were treated successively with trypsin $(0 \cdot 25 \%, 1.5 \mathrm{~min})$ and $3 \%$ hydrogen peroxide in methanol $(20 \mathrm{~min})$ and washed in PBS. All subsequent procedures were performed at room temperature, washes were in PBS, and incubations were in a humid chamber. Sections were treated with first with Superblock (40 min; DAKO, Carpenteria, CA, USA) and then with the monoclonal antibody to BrdU (clone BU $-33,4 \mu \mathrm{l} / \mathrm{ml}$ in PBS, $1 \mathrm{~h}$; Sigma). Following washes, biotinylated rabbit anti-mouse IgG was added (1:300 in PBS, 30 min; Zymed, California, USA). Sections were washed and incubated first in ABC complex (40 min; Vectastain Elite, Vector Laboratories, Burlingame, CA) and then with Tyramide Signal Amplification Biotin reagent (30 min; PerkinElmer Life Sciences, Inc, Boston, MA, USA) according to the manufacturers' instructions. After washing, diaminobenzidine (DAB) was added to reveal sites of antibody binding with a dark brown reaction product (2-3 min; DAKO Liquid DAB Substrate Chromogen System), and sections were counterstained with Mayer's Haematoxylin (3 min; Sigma), blued in Scott's tap water (1 min), and finally dehydrated and mounted in Depex (BDH Laboratory Suppliers, Poole, Dorset, UK) under glass coverslips. Cell types with anti-BrDU nuclear staining were identified on the basis of their location within the cord and the size and shape of cell nuclei, as described above.

The percentage of BrdU labelled cells was assessed using an unbiased counting frame of $430 \mu \mathrm{m}^{2}$. To determine the proliferation index for each cell type, the total number of BrdU-labelled cells was divided by the total number of labelled and unlabelled cells.

\section{Apoptosis analysis}

Tissue sections $(5 \mu \mathrm{m})$ were deparaffinized and rehydrated prior to the detection of DNA fragmentation (see Fig 1B). Apoptotic cells were detected using the terminal deoxynucleotidyl transferase (TdT)-mediated dUTP-biotin nick-end labelling (TUNEL) method (Meachem et al. 1999). Apoptotic cells were visualised using the chromogen $\mathrm{DAB}$ and processed as described for BrDU detection. On control sections, the TdT enzyme was omitted. TUNEL-positive cell types were identified based on their location within the cord, their size, and the shape of the cell nucleus.

The percentage of cells with TUNEL labelling was assessed using an unbiased counting frame of $430 \mu \mathrm{m}^{2}$ and the apoptotic index calculated by dividing the number of TUNEL labelled cells by the total number of labelled and unlabelled cells. 

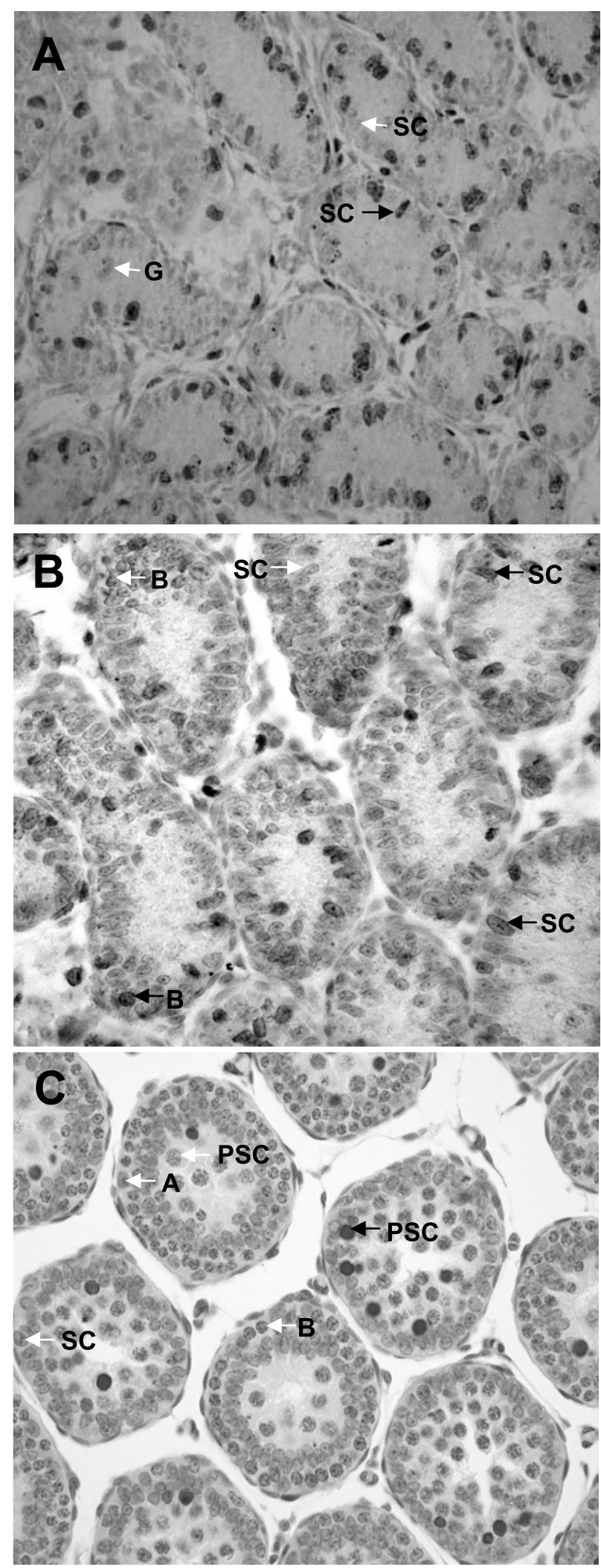

Serum androgen levels

Serum androgen levels were measured by RIA using iodinated histamine-testosterone in combination with an acidic buffer ( $\mathrm{pH}$ 5.1) to disrupt binding between testosterone and binding proteins in unextracted serum samples

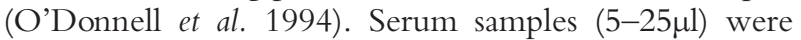
assayed in duplicate across two assays. Within assay variation for both assays was 3\%, and between assay variation was $9 \%$. Assay sensitivity was $0.6 \mathrm{ng} / \mathrm{ml}$.

\section{Serum inhibin levels}

Immunoreactive inhibin was measured by heterologous RIA as described previously (Robertson et al. 1988). Results are expressed in terms of an in-house rat ovarian extract calibrated against human recombinant (hr)inhibin. Iodinated hr-inhibin was used as tracer. The antiserum used was rabbit antiserum (\#1989) which is directed towards the $\alpha$-subunit thereby measuring both inhibin A and B, and cross-reacts $288 \%$ with pro--C, the prosequence of the inhibin alpha subunit (Robertson et al. 1989). Goat anti-rabbit IgG (GAR\#12; Monash Institute of Reproduction \& Development, Monash University, Melbourne, Australia) was used as second antibody. The assay buffer used was 0.01 M PBS containing 0.5\% BSA (Sigma). Mouse serum pools diluted in a dose-dependent manner and were parallel to the standard curve (data not shown). The samples were run in a single assay in $20 \mu \mathrm{l}$ duplicates. The within-assay variation was $7 \cdot 2 \%$. Assay sensitivity was $0 \cdot 17 \mathrm{ng} / \mathrm{ml}$.

\section{Oligonucleotide microarray hybridisation}

To identify genes regulated by FSH at the 18 day time point, total RNA was isolated from total testes using acid phenol extraction (Chomczynski \& Sacchi 1987). RNA from two individual animals treated from $14 \mathrm{dpp}-18 \mathrm{dpp}$ with either FSHAb or ConAb (4 samples in total) was used. The gene expression profile of FSHAb- and ConAb-treated testis were individually determined using Affymetrix RG_U34A rat chips (Affymetrix Inc., Santa Clara, CA, USA) as previously described (McLean et al. 2002). The RNA from the FSHAb- and the

Figure 1 Representative photomicrographs of cross sections of the testis from rats receiving normal sheep immunoglobulin for up to 4 days. Panel $\mathrm{A}$. BrdU incorporation in the 3 dpp rat testis detected by immunohistochemistry. White arrows: nucleus of unlabelled Sertoli cell (SC) and gonocyte (G). Black arrow: nucleus of a labelled Sertoli cell. Panel B. BrdU incorporation in the $9 \mathrm{dpp}$ rat testis. White arrows: nucleus of unlabelled Sertoli cell (SC) and type B spermatogonia Black arrows: nucleus of labelled Sertoli cell (SC) and type B spermatogonia. Panel C. DNA fragmentation indicative of cellular apoptosis detected by TUNEL in $18 \mathrm{dpp}$ rat testis. White arrows: nucleus of unlabelled Sertoli cell (SC), type B spermatogonia (B) and pachytene spermatocyte (PSC). Black arrows: nucleus of labelled pachytene spermatocytes (PSC). 
ConAb-treated testis was extracted and purified before biotin labelling and hybridisation to the microarray gene chip. Two replicates of each sample were hybridised to separate chips giving a total of four chips in the analysis. Each gene set on the Affymetrix chip is composed of 16 pairs of 24-mer oligonucleotides, with 8799 genes on each RG_U34A chip. Included in each set is one anti-sense strand specific for the gene and one anti-sense strand with single point mutations is used as a comparative negative control. The labelled RNA was visualized on a Hewlett-Packard Gene Array Scanner (Hewlett-Packard Co., Palo Alto, CA, USA). An initial two way comparison was performed using the Affymetrix Suite software. In both experiments the FSHAb- and ConAb-treated chips were compared against each other.

\section{Bioinformatics and microarray statistics}

The bioinformatics and statistical analysis performed is as previously described (Eisen et al. 1998, Chaudhary et al. 2005, Kezele et al. 2002). Microarray output was examined visually for excessive background noise and physical anomalies. The default Microarray Suite (MAS, Silicon Genetics, Redwood City, CA, USA) statistical values were used for all analyses. An absolute analysis using MAS was performed to assess the relative abundance of the transcripts based on signal and detection (present, absent, or marginal) for the 16 different oligonucleotides per gene and comparison for analysis. The absolute analysis from MAS was imported into GeneSpring 5.1 software (Silicon Genetics, Redwood City, CA, USA). The data were normalized within GeneSpring using the default/ recommended normalisation methods. These include setting of signal values below $0 \cdot 01$ to $0 \cdot 01$, total chip normalisation to the 50th percentile, and normalisation of each gene to the median. These normalisations allowed for the comparison of data based on relative abundance in any sample set rather than compared with a specific control value. Transcripts expressed differentially at a statistically significant level were determined using a one-way ANOVA parametric test with variances not assumed equal, and a $P$-value cutoff of $0 \cdot 05$. This was applied to all samples and considered all transcripts represented on the arrays. Two independent samples for each treatment group were analyzed was performed and allowed a $2 \times 2$ factorial comparison in the experiment. Subsequently, expression restrictions were applied to identify the transcripts expressed in a significant manner. These restrictions were designed so that the remaining transcripts met the following requirements in addition to being expressed in a significant manner: 1) each transcript have a signal value of at least 100 in the average of both samples, from at least one of the treatments tested and 2) had an average fold change of 1.5 or greater in signal intensity between treatments. Transcripts that passed these restrictions were considered for further analysis. Previous studies have shown that microarray data correlates well with real-time quantitative PCR and Northern analysis (Eisen et al. 1998, Chaudhary et al. 2005, Kezele et al. 2002, SadateNgatchou et al. 2004). Therefore, microarray data does not need to be confirmed as previously suggested (Shima et al. 2004). However, two selected genes were used in a real-time quantitative PCR procedure as previously described (McChlery \& Clarke 2003) to help confirm the microarray procedure. The microarray chip data can be accessed at www.skinner.wsu.edu.

\section{Reverse transcription $(R T)$ and real-time $P C R$ analysis}

Real time PCR was used to measure the relative levels of two candidate FSH-regulated genes. Total RNA collected from two individual day 18 rats treated with either $\mathrm{ConAb}$ or with $\mathrm{FSH} \mathrm{Ab}$ for 4 days was treated to remove residual genomic DNA (Ambion DNA-free Treatment Kit; Ambion, Austin TX, USA). RNA (500 ng) was converted to cDNA in a final volume of $20 \mu \mathrm{l}$ using Superscript II according to the manufacturer's protocol (Invitrogen). For each sample, the absence of contaminating genomic DNA in cDNA samples was confirmed using reactions in which the RT enzyme was omitted. Quantitative RT-PCR analysis was performed using the Roche LightCycler (Roche, Mannheim, Germany) and the FastStart DNA Master SYBR-green 1 system (Roche). Oligonucleotide primer sequences for IGFBP-3, Smad3, and beta-actin were obtained either from published sources or Frodo.wi. mit.edu/cgi-bin/primer3/primer3_www.cgi;version 3.0 (Table 1). For PCR analysis, sample cDNA was diluted 1:10- to 1:50-fold, and PCR reaction conditions, including $\mathrm{Mg}^{2+}$ concentration, primer concentration, anneal time and extension time were optimized for each primer pair as summarized in Table 1. For all PCR analyses, standard curves were generated using dilutions of an immature rat testicular cDNA preparation of arbitrary units (i.e. $17 \mathrm{dpp}$ ). PCR of all standards and samples were performed using duplicate reactions for approximately 40-45 cycles, after which a melting curve analysis was performed to monitor PCR product purity (see Table 1). In initial experiments, PCR product identities were verified by agarose gel electrophoresis and DNA sequencing (data not shown).

\section{Statistics}

A two-sample $t$-test was used to determine differences between FSHAb and ConAb treated samples with the assumption that data were normally distributed for all histological and hormone data. If data did not show normal distribution, then a Mann-Whitney test was carried out using Sigmastat for Windows version 2.0 (Jandel Corporation, CA, USA). Data are expressed as mean \pm S.E.M., $n=7$ rats per group. Statistical analysis of microarray data is described in Bioinformatics and microarray statistics. 


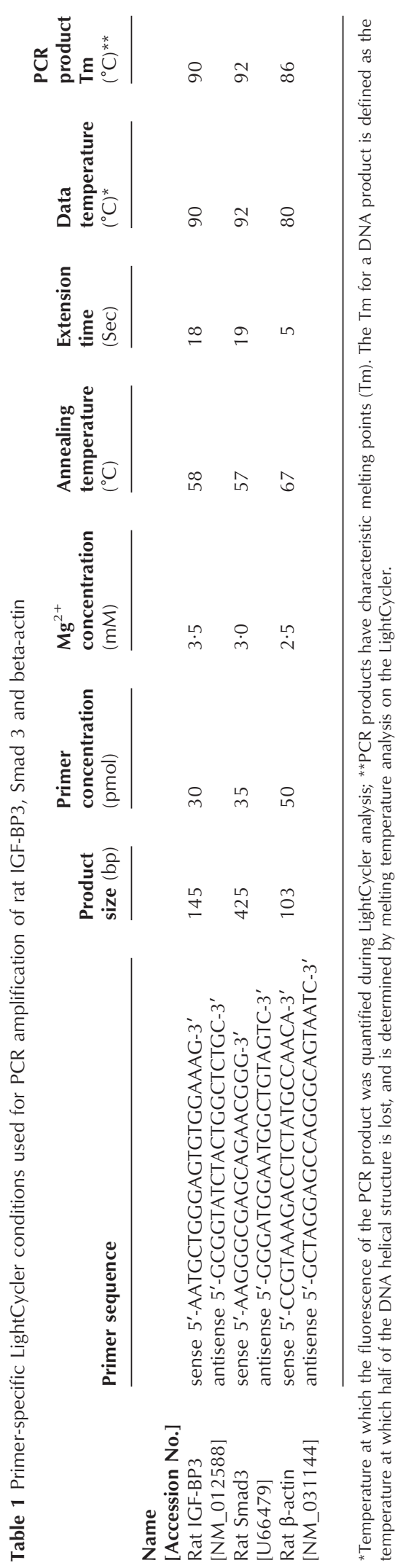

\section{Results}

Testicular weights and serum hormone measurements

Testicular weights were not significantly different following 2 days of FSH suppression in 3 dpp rats compared with their corresponding controls (Table 2), however testicular weights were reduced in 9 and 18 dpp animals after 2 (to $84 \%$ of control) and 4 days (to $78 \%$ of control) of FSH suppression. FSH suppression did not affect serum androgen levels at any time point compared with controls (Table 2). Serum inhibin levels following 2 days of FSH suppression in 3, 9 and 18 dpp rats were significantly reduced to $74 \%, 71 \%$ and $69 \%$, and after 4 days $73 \%$ and $53 \%$ in 9 and $18 \mathrm{dpp}$ rats compared with control values, respectively (Table 2). This reduction in circulating inhibin levels is presumed to reflect the successful neutralisation of FSH bioactivity through administration of the antibody raised against FSH, as FSH normally stimulates production of inhibin from Sertoli cells.

\section{Cell populations decreased in FSH withdrawn rats}

At 3 dpp there were no differences in gonocyte $(0 \cdot 098 \pm$ 0.010 vs $0.091 \pm 0.054$ million/testis) or Sertoli cell numbers $(3 \cdot 50 \pm 2 \cdot 4$ vs $3.50 \pm 2 \cdot 3$ million/testis) following 2 days of FSHAb treatment compared with ConAb treatment (Fig 2A), correlating no change in testis weight. At 9 dpp, there was a significant reduction (to $63 \%$ of control; $P<0 \cdot 05)$ in the number of Sertoli cells following 4 days of FSH suppression ( $16 \cdot 8 \pm 1 \cdot 7$ vs $23 \cdot 0 \pm 1 \cdot 7$ million/testis), while spermatogonial numbers were unchanged $(0.9 \pm$ 0.08 vs $1.1 \pm 0.4$ million/testis) (Fig 2B). At $18 \mathrm{dpp}$ no difference in the number of Sertoli cells were observed in response to 4 days of FSHAb treatment $(40 \cdot 2 \pm 3 \cdot 20$ vs $44 \cdot 2 \pm 4 \cdot 18 \mathrm{million} /$ testis $)$. A reduction in spermatogonia to $75 \%(16.9 \pm 1 \cdot 8$ vs $22 \cdot 2 \pm 1 \cdot 0$ million/testis, $P<0.05)$ of control group values was observed following 4 days of FSH suppression. Spermatocyte number tended to be reduced to $80 \%(12 \cdot 4 \pm 1 \cdot 1$ vs $15 \cdot 5 \pm 1 \cdot 0$ million/testis, $P=0 \cdot 061)$ of control group values was observed following 4 days of FSH suppression, although this did not achieve significance (Fig 2C).

\section{FSH suppression decreases Sertoli cell proliferation in day 9 rats}

At 3 dpp, no differences in Sertoli cell proliferation were observed between FSHAb- and ConAb-treated rats $(23 \cdot 4 \% \pm 3 \cdot 2$ vs $27 \cdot 2 \% \pm 1 \cdot 8)$; no BrdU labelled gonocytes were observed in these samples (Refer Fig 1). At $9 \mathrm{dpp}$, there was a significant reduction (to $66 \%$ of control, $P<0 \cdot 01)$ in the proliferation rate of Sertoli cells following FSH suppression $(14 \cdot 3 \% \pm 0.6$ vs $21 \cdot 6 \% \pm 1 \cdot 2)$ (Fig 2A), while no change was observed for spermatogonia $(23 \cdot 2 \% \pm 2 \cdot 4$ vs $21 \cdot 1 \% \pm 1 \cdot 6, \quad P=0 \cdot 11) \quad($ Fig $3 A)$. At 
Table 2 The testicular weights $(\mathrm{mg})$, serum testosterone $(\mathrm{ng} / \mathrm{ml})$ and inhibin $(\mathrm{ng} / \mathrm{ml})$ levels at $3 \mathrm{dpp}, 9 \mathrm{dpp}$ and $18 \mathrm{dpp}$ following 2 and 4 days of FSH suppression. Rats were treated with normal sheep immunoglobulin (ConAb) and with antibody raised against rat FSH (FSHAb) at $3 \mathrm{dpp}, 9 \mathrm{dpp}$ and $18 \mathrm{dpp}$ following 2 and 4 days of treatment. The data are expressed as mean \pm S.E.M., with $n=10$ rats/group.

\begin{tabular}{|c|c|c|c|}
\hline & $\begin{array}{l}\text { Testicular weight } \\
\text { (mg) }\end{array}$ & $\begin{array}{l}\text { Serum testosterone } \\
(\mathrm{ng} / \mathrm{ml})\end{array}$ & $\begin{array}{l}\text { Serum inhibin } \\
(\mathrm{ng} / \mathrm{ml})\end{array}$ \\
\hline \multicolumn{4}{|c|}{ Treatment } \\
\hline+ ConAb $2 d$ & $5 \cdot 1 \pm 0 \cdot 2$ & $0.64 \pm 0.08$ & $3 \cdot 57 \pm 0 \cdot 21$ \\
\hline+ FSHAb 2d & $5 \cdot 1 \pm 0 \cdot 1$ & $0 \cdot 63 \pm 0 \cdot 11$ & $2 \cdot 65 \pm 0.06^{* *}$ \\
\hline \multicolumn{4}{|c|}{9 days post partum } \\
\hline+ ConAb 2d & $17 \cdot 9 \pm 0 \cdot 9$ & $1 \cdot 36 \pm 0 \cdot 3$ & $4 \cdot 53 \pm 0 \cdot 3$ \\
\hline +FSHAb 2d & $15 \cdot 2 \pm 0 \cdot 5^{*}$ & $1 \cdot 18 \pm 0 \cdot 1$ & $3 \cdot 23 \pm 0 \cdot 2^{*}$ \\
\hline+ ConAb 4d & $18 \cdot 7 \pm 0 \cdot 4$ & $0 \cdot 89 \pm 0 \cdot 2$ & $4 \cdot 17 \pm 0 \cdot 24$ \\
\hline +FSHAb 4d & $14 \cdot 6 \pm 0 \cdot 5^{\star *}$ & $0 \cdot 70 \pm 0 \cdot 1$ & $3 \cdot 03 \pm 0 \cdot 19^{*}$ \\
\hline \multicolumn{4}{|c|}{18 days post partum } \\
\hline+ ConAb 2d & $75 \cdot 4 \pm 3 \cdot 0$ & $0 \cdot 92 \pm 0 \cdot 3$ & $3 \cdot 51 \pm 0 \cdot 4$ \\
\hline$+\mathrm{FSHAb} \mathrm{2d}$ & $63 \cdot 2 \pm 3 \cdot 4^{*}$ & $0 \cdot 92 \pm 0 \cdot 2$ & $2 \cdot 43 \pm 0 \cdot 2^{*}$ \\
\hline+ ConAb 4d & $74 \cdot 1 \pm 1 \cdot 2$ & $1 \cdot 80 \pm 0 \cdot 5$ & $5 \cdot 75 \pm 0 \cdot 31$ \\
\hline +FSHAb 4d & $57 \cdot 9 \pm 2 \cdot 1^{\star \star}$ & $1 \cdot 36 \pm 0 \cdot 2$ & $3 \cdot 09 \pm 0 \cdot 20^{* \star}$ \\
\hline
\end{tabular}

$18 \mathrm{dpp}$, in response to FSH suppression, there was no change in Sertoli cell $(6 \cdot 8 \% \pm 2 \cdot 3$ vs $9 \cdot 5 \% \pm 1 \cdot 0, P=0 \cdot 30)$, spermatogonial $(19 \cdot 6 \% \pm 1 \cdot 9$ vs $23 \cdot 3 \% \pm 1 \cdot 0, P=0 \cdot 11)$ or spermatocyte proliferation $(11.9 \% \pm 1 \cdot 4$ vs $10 \cdot 8 \% \pm 1 \cdot 7$, $P=0 \cdot 64$ ) (Fig 3B) compared with their corresponding controls. These data indicate that the reduction in testis weight due to FSH suppression at $9 \mathrm{dpp}$, but not at 18 $\mathrm{dpp}$, reflects the lower number of Sertoli cells in these samples. The incidence of apoptosis was next investigated as an alternative basis for the reduced testis weights in the 18 dpp samples (Fig 3B).

Germ cell apoptosis is affected by FSH suppression in 18 dpp rats

No apoptosis was observed in Sertoli cells and gonocytes at 3 dpp (Refer Fig 1). No differences in Sertoli cell $(0 \cdot 6 \% \pm 0.2$ vs $0.9 \% \pm 0 \cdot 2, P=0 \cdot 36)$ or spermatogonial apoptosis $(6 \cdot 6 \% \pm 1 \cdot 1$ vs $4 \cdot 6 \% \pm 0 \cdot 9, \quad P=0 \cdot 20)$ were observed following 4 days of FSH suppression at $9 \mathrm{dpp}$ compared with controls (Fig 4A). However, at $18 \mathrm{dpp}$, there was a significant elevation of spermatogonial apoptosis $(250 \%$ of control) in response to $\mathrm{FSH}$ suppression $(15 \cdot 5 \% \pm 1 \cdot 6$ vs $6 \cdot 2 \% \pm 1 \cdot 0, \quad P<0 \cdot 001)$; spermatocyte apoptosis increased to $136 \%$ of control levels $(16 \cdot 1 \% \pm 2 \cdot 2$ vs $11 \cdot 8 \% \pm 1 \cdot 4, P=0 \cdot 13)$, although this did not achieve significance (Fig 4B). No change in Sertoli cell apoptosis was observed at any time point (Fig 4). These data indicate that a shift occurs between 9 and $18 \mathrm{dpp}$ within the germ cell population towards reliance for support cues on FSH-derived products. The nature of this support system and the effects of its removal were examined using a genomic microarray to identify genes regulated by altered levels of FSH at 18 dpp.

\section{Microarray analysis}

Thirty genes were identified in the $18 \mathrm{dpp}$ samples as up-regulated and 30 as down-regulated (Table 3) following FSH suppression by treatment with FSHAb for 4 days. These 60 genes of interest met the selection criteria outlined previously; all give at least one signal intensity greater than 100, are flagged as changing, and have fold changes of 1.5 or greater.

Amongst these genes, 12 out of $60(20 \%)$ have previously been reported to be regulated by FSH, predominantly through in vitro studies. Many of the genes on this list have not yet been identified as being expressed in the testis $(26 / 60)$, and some of those known to be in the testis have not previously been assessed for regulation by FSH (14/34). This latter category of candidate in vivo FSH target genes have been reported to be expressed in Sertoli cells (4/14), germ cells (8/14) and/or non-Sertoli somatic cells (6/14); clearly the non-Sertoli cells expressed genes that would be regulated indirectly, through FSH regulation of Sertoli cell biosynthesis or other functions.

\section{$R T-P C R$ analysis}

IGFBP-3 mRNA expression levels (measured in two individual animals) in FSHAb-treated rats were significantly elevated approximately $2 \cdot 5$-fold above the levels 

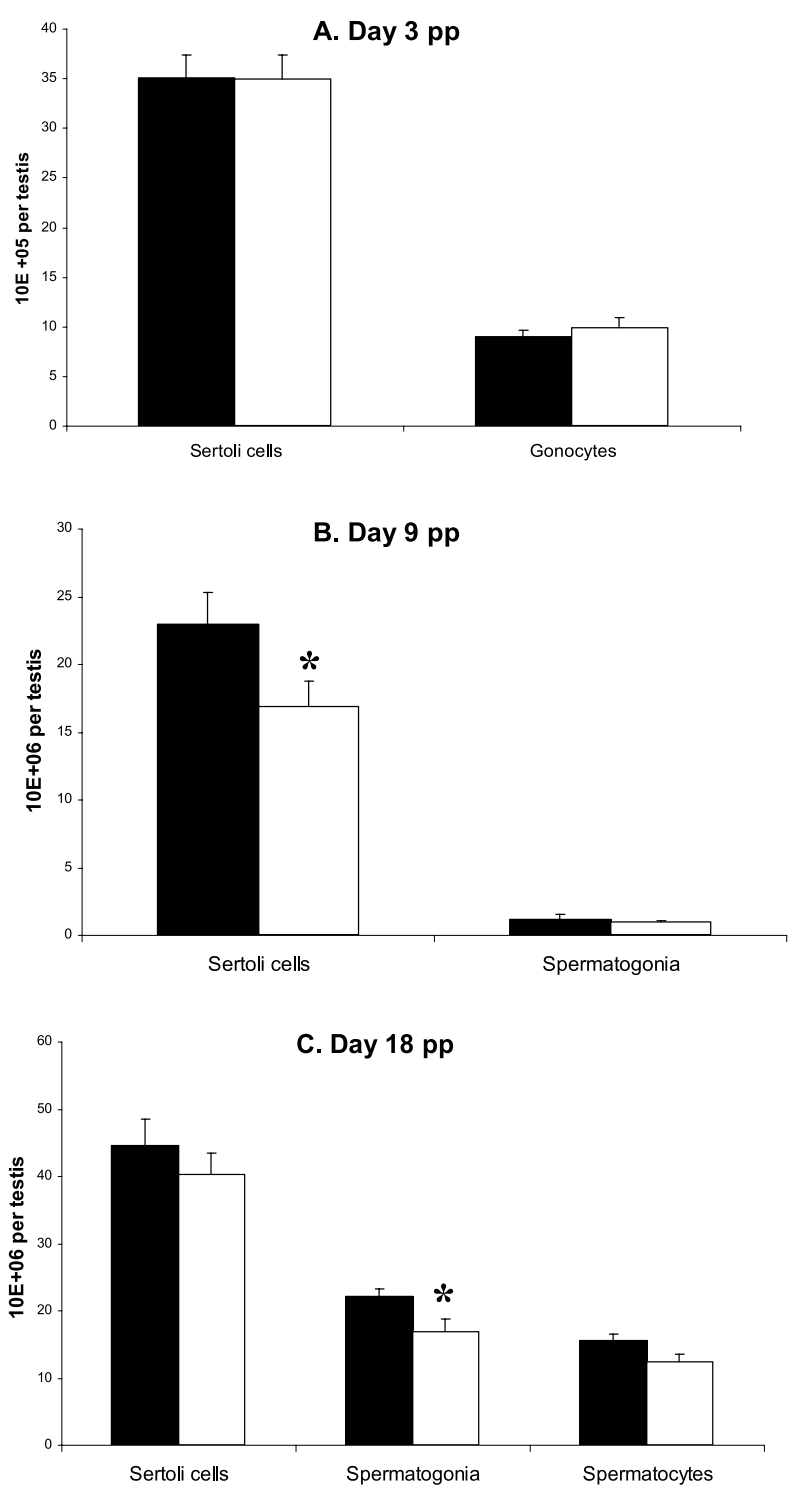

Figure 2 The number of Sertoli cells, spermatogonia and spermatocytes at $3 \mathrm{dpp}(\mathrm{A}), 9 \mathrm{dpp}$ (B) and $18 \mathrm{dpp}(\mathrm{C})$ following 2 and 4 days of FSH suppression. Cell numbers in rats treated with normal sheep immunoglobulin (black bars) and rats treated with antibody raised against rat FSH (white bars) at $3 \mathrm{dpp}, 9 \mathrm{dpp}$ and $18 \mathrm{dpp}$. Sertoli cell, spermatogonial and spermatocyte numbers are expressed as mean \pm S.E.M., where $n=7$ rats/group. Asterisk identify significant differences between treated and control groups at $P<0 \cdot 05$.

measured in two individual ConAb-treated rats. In contrast, Smad 3 mRNA expression was significantly reduced by approximately 6 -fold following FSHAb treatment compared with ConAb-treated rats (Fig 5).

\section{Discussion}

These data illustrate that the influence of FSH on Sertoli and germ cells are dynamic and cell-type specific during
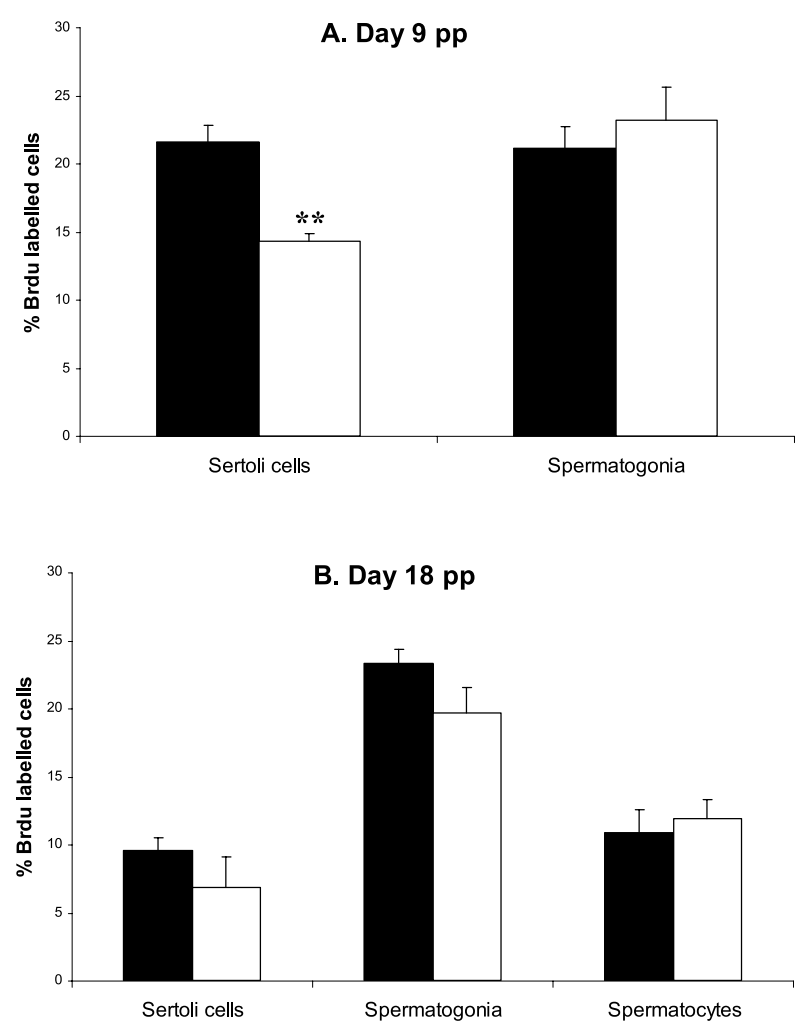

Figure 3 Proliferation of specific cell populations of the seminiferous epithelium at $9 \mathrm{dpp}(\mathrm{A})$ and $18 \mathrm{dpp}$ (B) following 4 days of FSH suppression. Percentage of cells incorporating BrdU in rats treated with normal sheep immunoglobulin (black bars) and rats treated with antibody raised against rat FSH (white bars) at $9 \mathrm{dpp}$ and $18 \mathrm{dpp}$. The percentages of labelled versus unlabelled total cells, Sertoli cells, spermatogonia and spermatocytes are expressed as mean \pm S.E.M., where $n=7$ rats/group. Asterisks denote significant differences between treated and control groups at $P<0 \cdot 01$.

the first spermatogenic wave in the rat. We developed this model to enable a co-ordinated documentation of specific cellular changes, in association with the identification of testicular genes, for which expression is affected by variance in bioactive FSH levels. The results are in accord with previous observations that FSH and activin regulate Sertoli and germ cell proliferation in an age-dependent manner in vitro (Boitani et al. 1995, Fragale et al. 2001). Our findings expand on earlier analyses by measuring proliferation and apoptosis in the same samples and establishing a method for identification of FSH target genes in vivo. More specifically, this study demonstrated for the first time in vivo that acute FSH suppression reduces both the Sertoli and germ cell populations, first by inhibiting Sertoli cell proliferation from 5 to $9 \mathrm{dpp}$, and later by inducing germ cell apoptosis between 14 and $18 \mathrm{dpp}$ (see Fig 6).

Acute suppression of FSH for 4 days resulted in decreased testis weights in 9 and $18 \mathrm{dpp}$ rats. This decrease 

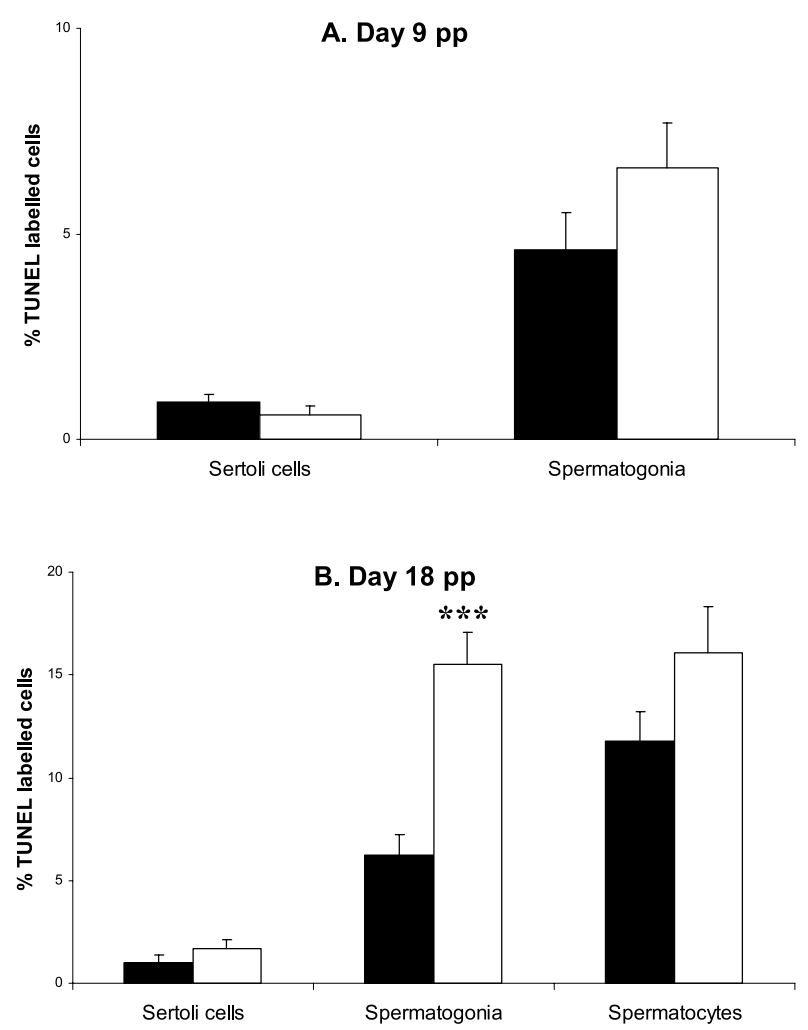

Figure 4 Apoptosis in specific cell populations of the seminiferous epithelium at $9 \mathrm{dpp}(\mathrm{A})$ and $18 \mathrm{dpp}$ (B) following 4 days of FSH suppression. The percentages of TUNEL labelled cells in rats treated with normal sheep immunoglobulin (black bars) and rats treated with antibody raised against rat FSH (white bars) at $9 \mathrm{dpp}$ and $18 \mathrm{dpp}$. The percentages of labelled versus unlabelled total cells, Sertoli cells, spermatogonia and spermatocytes are expressed as mean \pm S.E.M., where $n=7$ rats/group. Asterisks denote significant differences between treated and control groups at $P<0 \cdot 001$.

in testicular weight was attributed, at least in part, to the decreased Sertoli cell population at $9 \mathrm{dpp}$ and a decreased germ cell population in $18 \mathrm{dpp}$ rats as assessed by the optical disector stereological technique. The Sertoli cell population decrease resulted from inhibition of proliferation and not from elevated apoptosis. In contrast, the reduction in spermatogonial and spermatocyte cell number at $18 \mathrm{dpp}$ resulted from elevated apoptosis of germ cells.

\section{Sertoli cell development}

Our findings are in accord with other studies which show that FSH plays a central role in regulating the size of the Sertoli cell population (Meachem et al. 1996) by supporting Sertoli cell proliferation during early postnatal life (Orth 1984, Orth et al. 1988, Boitani et al. 1995). Whether FSH plays a role in terminating Sertoli cell proliferation around 15 days after birth is beyond the scope of this study, however data from other in vitro and in vivo studies indicate a role for FSH in this process (Baker \& O'Shaughnessy 2001, Buzzard et al. 2002). Survival of Sertoli cells in the postnatal rat does not appear to be influenced by FSH levels, as evidenced by the fact that FSH suppression did not induce Sertoli cell apoptosis, though the possibility remains that there are residual levels of serum FSH in this model which are sufficient to support Sertoli cell survival. We predict that a greater impact on testicular physiology could be apparent if complete FSH withdrawal were achieved.

Several other factors have been demonstrated to regulate Sertoli cell development in the time interval under investigation here, including thyroid hormone (Cooke \& Meisami 1991, Van Haaster et al. 1992), activin (Boitani et al. 1995, Fragale et al. 2001, Buzzard et al. 2003), glial cell line-derived neurotrophic factor (GDNF) (Hu et al. 1999), interleukin-1 (Petersen et al. 2002), and transforming growth factor (TGF) and epidermal growth factor (Petersen et al. 2001). Interactions between these factors and FSH-mediated regulation of Sertoli cell function is not well understood, though two previously identified FSH regulated target genes, cyclin D2 (Buemer et al. 2000) and DMRT-1 (Raymond et al. 2000) are potential mediators.

In this study, the FSHAb dose administered was five times higher than that previously shown to neutralise greater than $90 \%$ of serum FSH in adult rats (Meachem et al. 1998, 1999). This dose was selected because serum FSH levels are 3-5 higher during postnatal life than in adulthood, as measured using RIA (Kirby et al. 1992). In our previous studies with this antibody, neutralisation of bioactive material was determined using an FSH in vitro bioassay, based on the induction of aromatase activity in immature rat Sertoli cells and assay of free FSH from rat serum using HPLC and RIA (Meachem et al. 1998, 1999). The significant reduction in serum inhibin levels following FSHAb administration in the present study are a positive indicator of the efficacy of FSH immunoneutralisation. Whether FSH regulates Sertoli cell development in the $3 \mathrm{dpp}$ testis remains unclear. Our data suggest that Sertoli cell proliferation and apoptosis are not governed by FSH between 1 and $3 \mathrm{dpp}$ in the rat. Consistent with this, Buzzard et al. (2003) reports that proliferation of purified Sertoli cells from rats younger than 6 dpp is not affected by FSH. On the other hand, Boitani et al. (1995) and Meehan et al. (2000) reported that Sertoli cell proliferation in $3 \mathrm{dpp}$ rat testis fragment cultures was enhanced in the presence of FSH. Differences between our new data and that reported in earlier studies may reflect differences between in vitro and in vivo models, with the latter being uniquely employed in the present study. It is possible that removal of FSH for 2 days in vivo may be insufficient to observe a subtle but functionally important change in Sertoli cell proliferation at this age, due to this relatively small population of Sertoli cells present at this time ( $<4$ million Sertoli cells/ 3 dpp testis). It may be necessary to extend the period of FSH suppression or to 


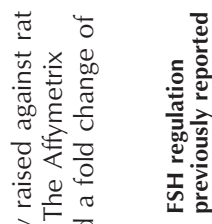

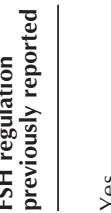

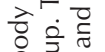

突

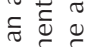

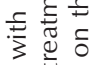

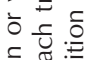

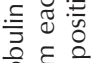

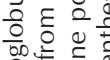

此

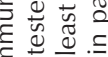

푼

यับ

징

등 웡

요은

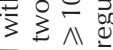

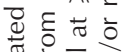

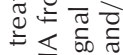

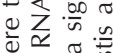

$3 \varepsilon \stackrel{0.00}{0}$

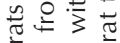

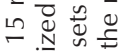

สิ

ये के ह

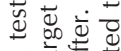

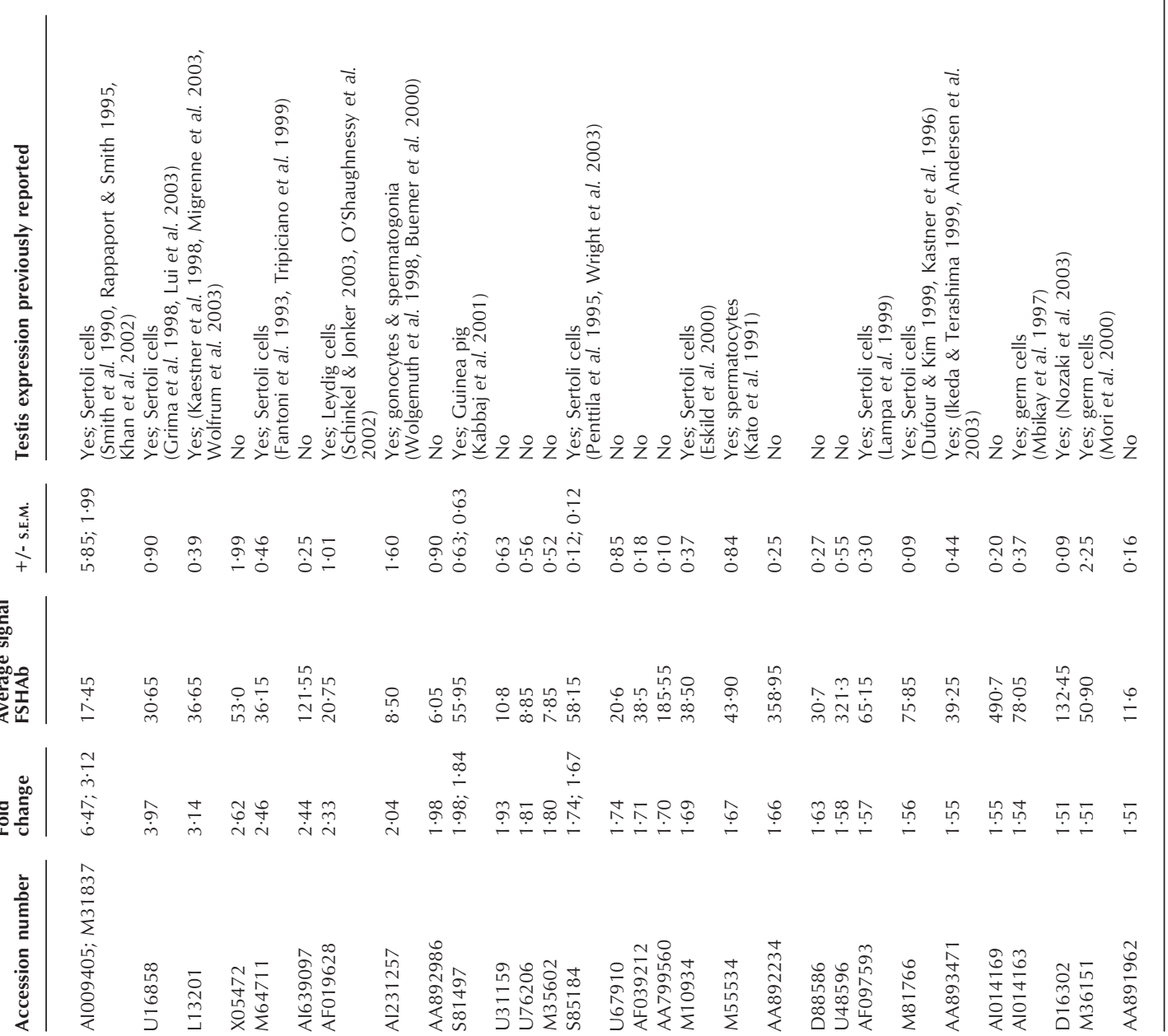

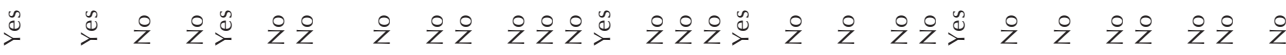

픈

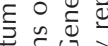

일

S.

20

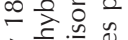

ते त्र

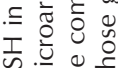

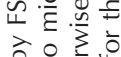

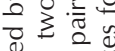

흔 등

总

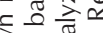

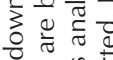

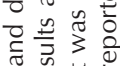

원

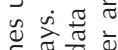

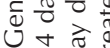

的市

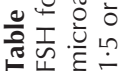

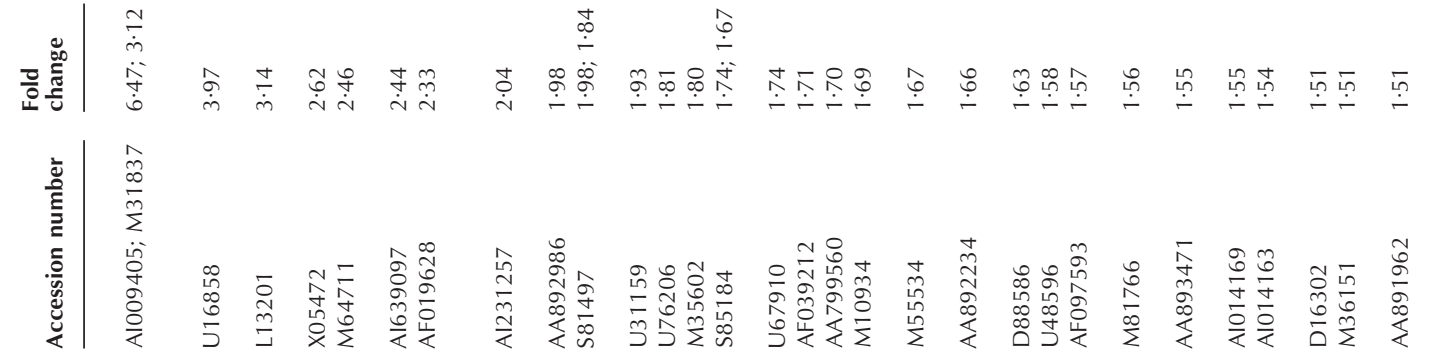

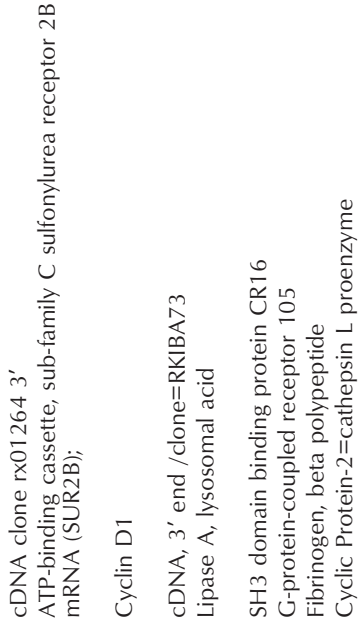
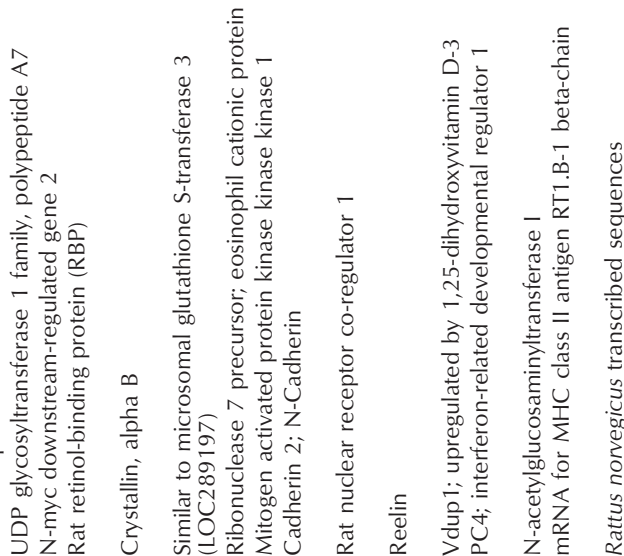

www.endocrinology-journals.org 

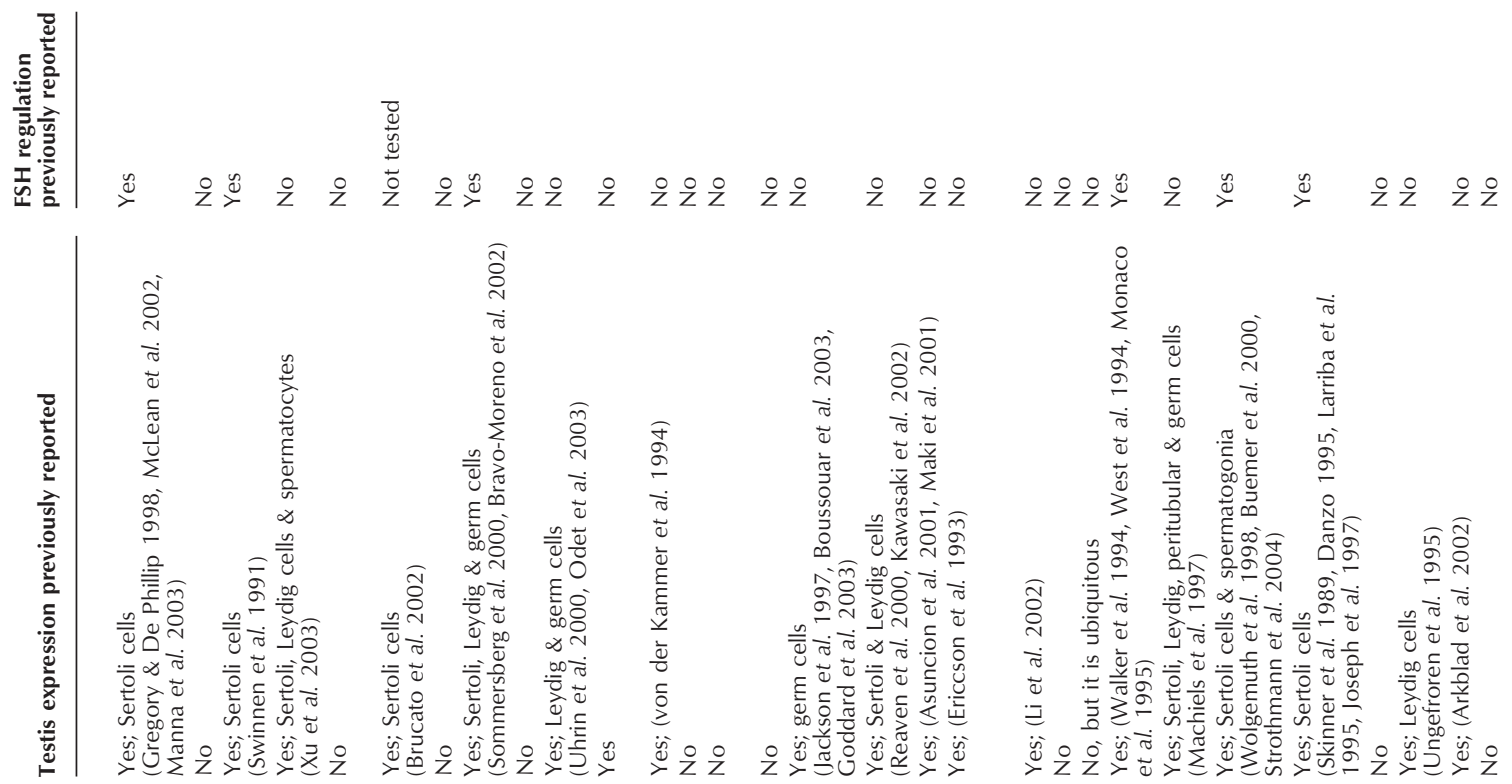

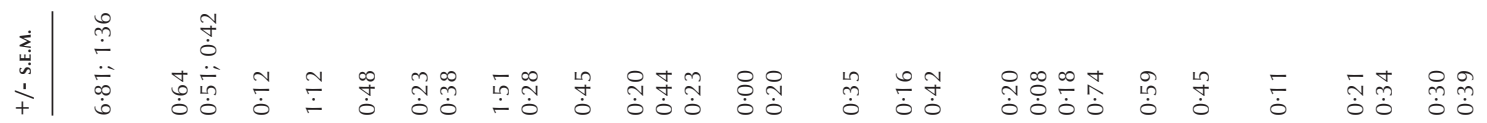

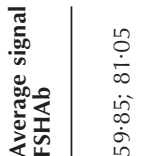

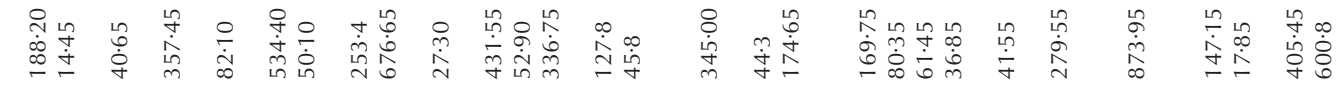

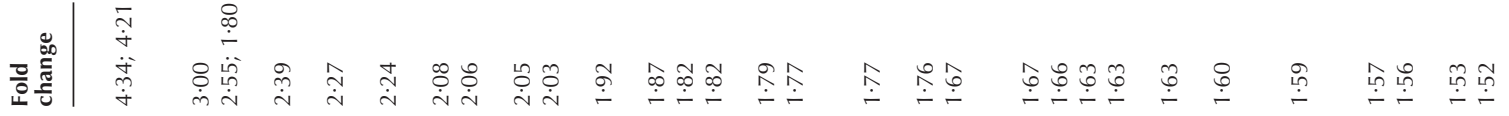
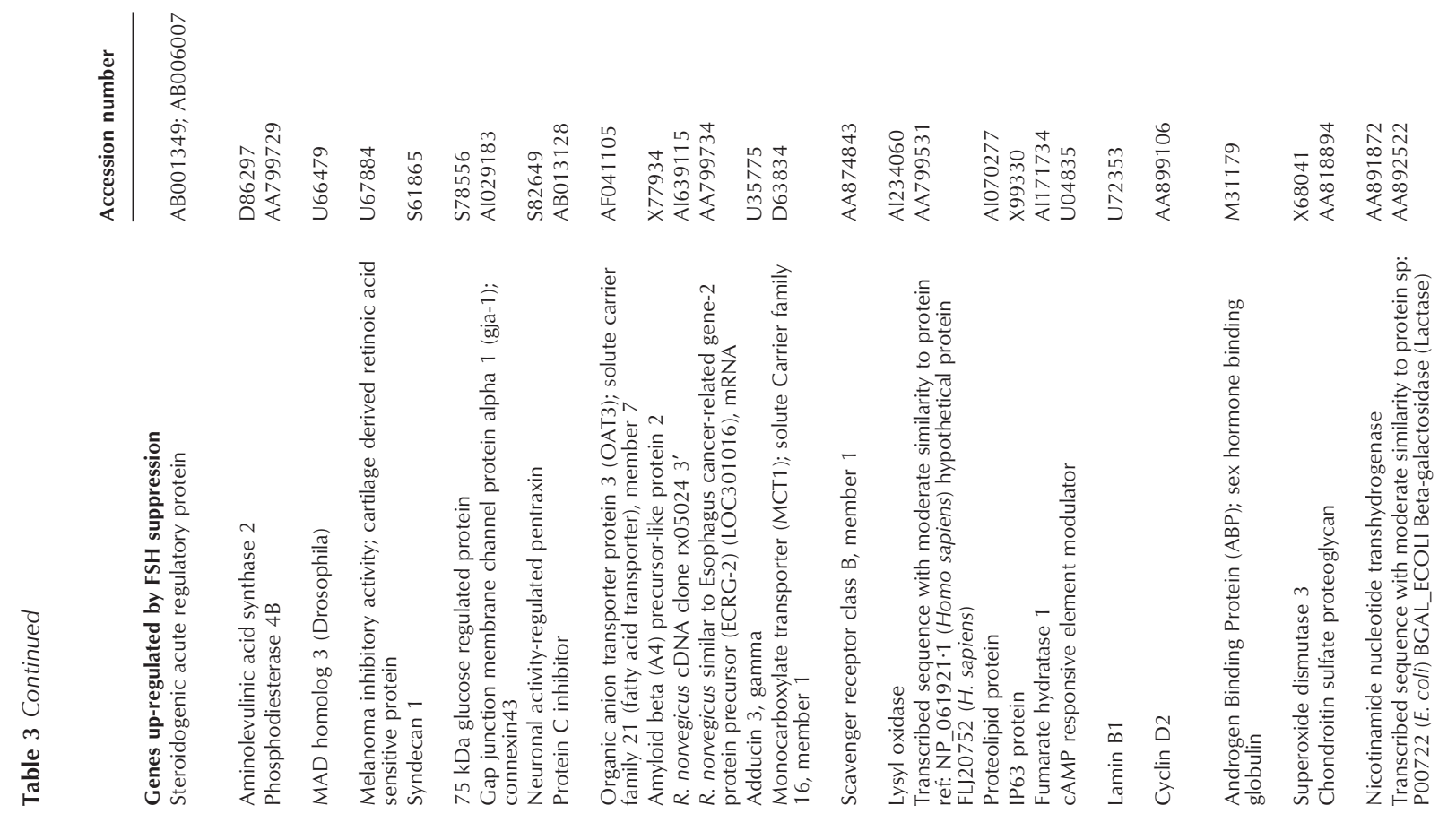

www.endocrinology-journals.org

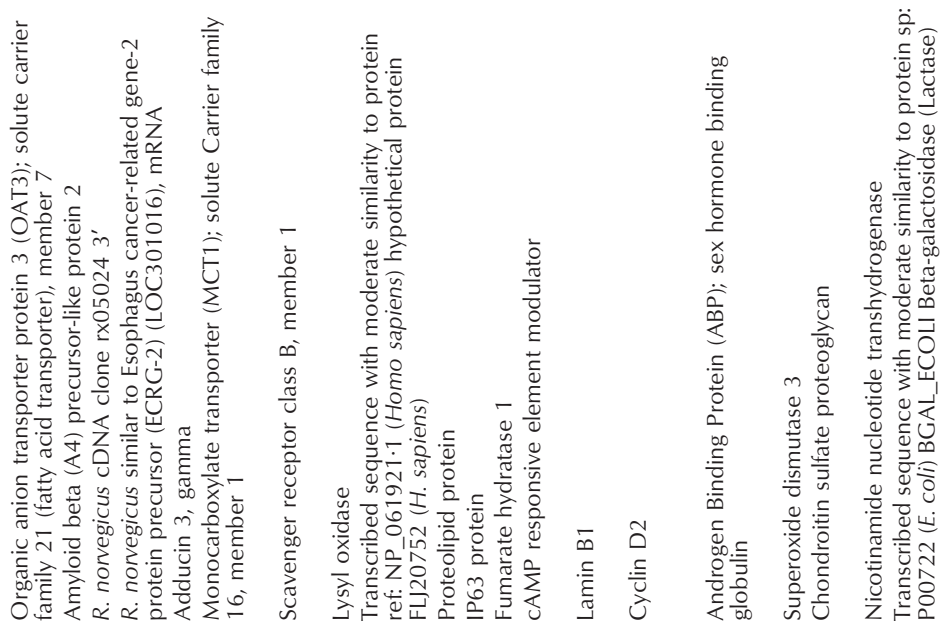



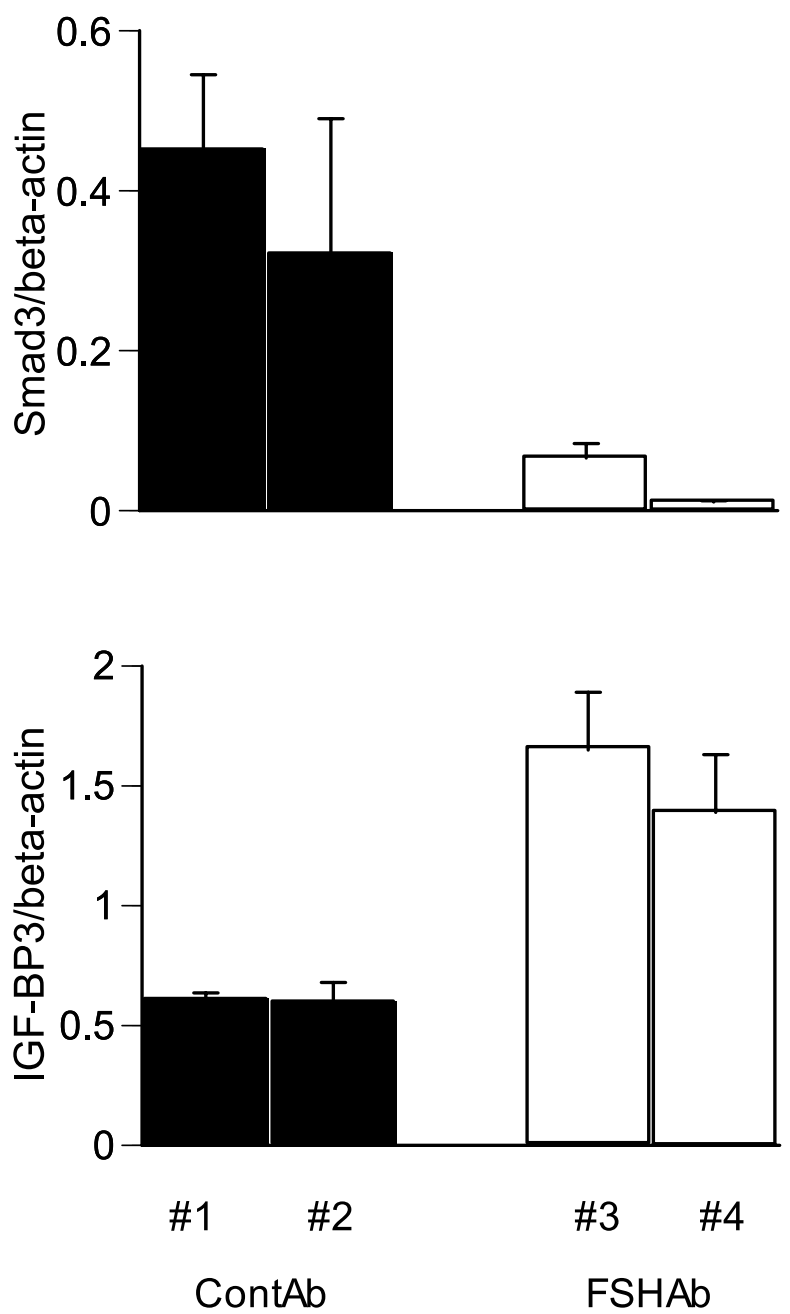

Figure 5 Expression levels of rat Smad 3 and IGFBP-3 by real time PCR. Two rats treated with normal sheep immunoglobulin (black bars) and treated with antibody raised against rat FSH (white bars) were tested to validate data obtained from the microarray analysis. Each sample was measured over three separate experiments in terms of ng of mRNA normalised to beta actin. Data are mean \pm S.D.

increase the dose of neutralising antibody if in fact residual levels of FSH exist. The Sertoli cell numbers measured in control antibody-treated groups in this study are in accord with our previous study (Meachem et al. 1996) and that of others (Simorangkir et al. 1997), reporting numbers quantified by the optical disector stereological technique, in rats of similar ages.

\section{Germ cell development}

These data provide no evidence that FSH supports the maturation of gonocytes into type A spermatogonia. Studies of congenitally deficient hypogonadal mice (hpg) lacking both FSH and LH show that gonocyte number is not altered in these newborn mice compared with wildtype controls, however gonocyte number is significantly reduced at $5 \mathrm{dpp}$, suggesting that gonocyte survival may be in part regulated by gonadotrophins. Whether this is an effect specific to FSH is yet to be elucidated (Baker \& O'Shaughnessy 2001). Several other recent studies highlight the impact of locally produced members of the TGF $\llcorner$ superfamily on germ cell development, including bone morphogenetic protein 4 (BMP4) (Pellegrini et al. 2003), activin (Boitani et al. 1995, Meehan et al. 2000) and GDNF (Meng et al. 2000, Yomogida et al. 2003), and production of both inhibin (an activin antagonist) and GDNF is regulated by FSH (Tadokoro et al. 2002). Meehan et al. (2000) provides in vitro evidence, using 1 and 3 day cultures of 3 dpp rat testis fragments, that FSH plus follistatin mediates gonocyte maturation into type A spermatogonia, but that FSH alone does not support gonocytes, as assessed on a per Sertoli cell basis. Meehan's study reported that activin independently elevated gonocyte number 4-fold above that of DMEM treated fragments and that follistatin prevented this activin-induced rise, giving rise to the concept that balance between activin and follistatin can influence germ cell maturation at the onset of spermatogenesis. Another facet of first wave initiation, gonocyte migration, relies at least in part on the interaction of c-kit and its FSH-regulated ligand, SCF (Orth et al. 2000), and it is apparent that the population of migratory gonocytes have stem cell activity, while those lacking pseudopods are undergoing apoptosis (Orwig et al. 2002). Thus influence of FSH at this age may reflect a complex set of interacting signals.

Several lines of evidence indicate that FSH enables spermatogonial survival in the adult rat, (Shetty et al. 1996, Meachem et al. 1999) without directly enhancing germ cell proliferation in vivo (McLachlan et al. 1995). In immature rats rendered FSH- and LH-replete by hypophysectomy, administration of FSH reduced the number of degenerating cells (Russell et al. 1987) and prevented germ cell apoptosis (Tapanainen et al. 1993). Evidence from culture of adult rat seminiferous tubules (Henriksen et al. 1996) and of immature rat testis fragments (Boitani et al. 1993) indicates that FSH also enhances proliferation of differentiated spermatogonia in vitro. The significant reduction in the spermatogonial population after 4 days of FSH suppression in the current study provides evidence that FSH influences survival of germ cell populations from 14-18 dpp. The reduction in germ cell number reduction appears attributable to a $2 \cdot 5$-fold higher apoptotic index compared with control levels, not to a change in proliferation rate. We also observed that spermatogonial numbers were not influenced by FSH at 9 days after birth, and this finding is inconsistent with in vitro data (Boitani et al. 1995). Low levels of circulating FSH may be present in the animals examined in this study; this may be sufficient to support spermatogonial development, as small increases in FSH can significantly impact the recovery of 


\section{Day 3}

Day 9
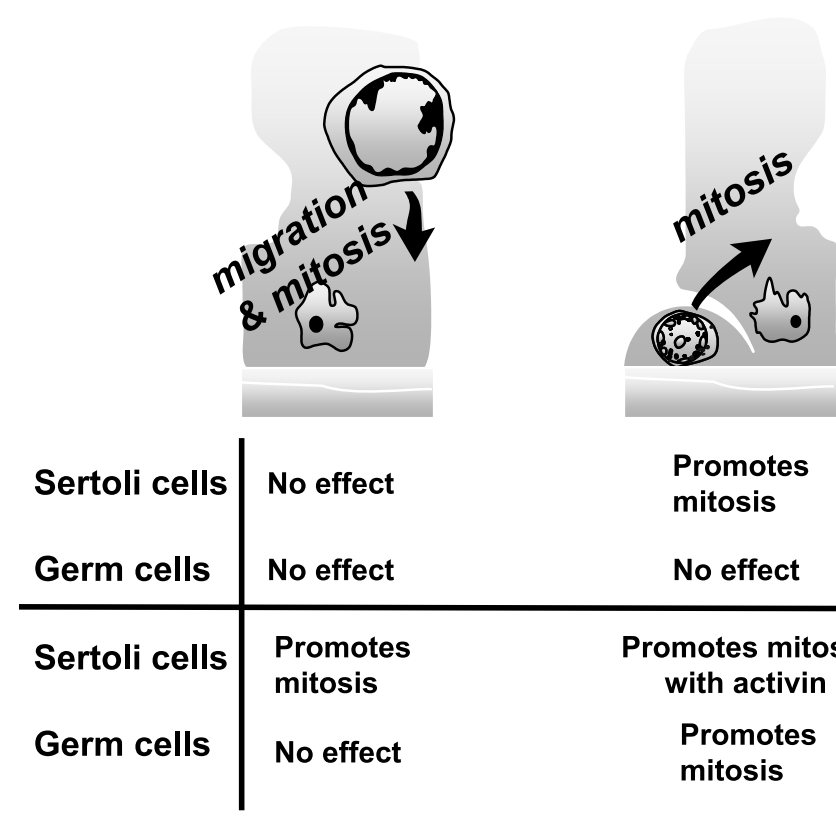

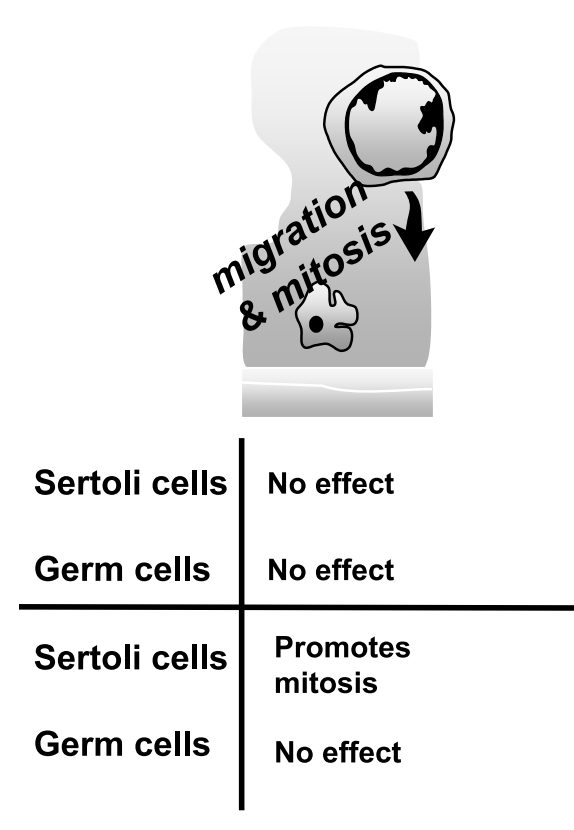

Germ cells

Sertoli cells

Germ cells

\section{Day 18}

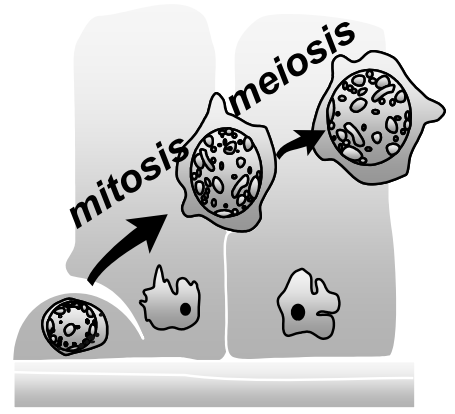

No effect

In vivo
Enhances survival

No effect

No effect

(this study)

Promotes mitosis

with activin

Promotes

mitosis
In vitro

Boitani et al. 1995,

Meehan et al. 2000 ,

Fragale et al. 2001

No cell survival

data reported

Figure 6 Dynamic effects of FSH on Sertoli and germ cell development during first wave in rats assessed through in vivo and in vitro analyses. Time points listed illustrate progressive maturation of germ cells and Sertoli cells in the first wave of spermatogenesis in rat. At $3 \mathrm{dpp}$, Sertoli cells are proliferating and gonocytes are re-entering the cell cycle and migrating to the basement membrane of the seminiferous cord to become undifferentiated and stem cell spermatogonia. At $9 \mathrm{dpp}$, proliferating Sertoli cells and differentiating spermatogonia are observed. By $18 \mathrm{dpp}$, Sertoli cell proliferation has ceased, and the cords have transformed into seminiferous tubules as tight junctions form between Sertoli cells and vectorial secretion from this epithelium commences. Germ cells that have progressed to the pachytene stage of meiosis are predominant in the seminiferous tubules. In this study, suppression of FSH by passive immunisation for 2 and 4 days revealed the age-dependent differential in vivo affects of FSH on Sertoli and germ cells: promotion of Sertoli cell mitosis at $9 \mathrm{dpp}$ and increasing germ cell viability at $18 \mathrm{dpp}$. These data are in agreement with previous in vitro observations that FSH regulates Sertoli cell proliferation in an age-dependent manner, interacting with activin to promote Sertoli proliferation and germ cell development at discrete ages. This comparison also highlights differences that may specifically reflect the use of in vitro versus in vivo models.

spermatogonial number in adult rats (Meachem et al. 1998). In the present study, spermatogonial number was assessed using a sensitive, unbiased optical disector method appropriate for counting these cells. Effects of lowered FSH levels may have been masked due to factors associated with counting a small population of cells. Spermatogonial and spermatocyte numbers in control antibody-treated rats in this study were in accord with our (Meachem et al. 1996) and that of others (Simorangkir et al. 1997) reporting data that were assessed in rats of similar ages by the using the optical disector technique.

Age dependent changes in cell survival resulting from FSH suppression may be due to developmentally regulated changes in the cellular synthesis of apoptotic regulators, such that documented for members of the Bcl-2 family during the first wave of mouse spermatogenesis (Meehan et al. 2001). The Bcl-w (Yan et al. 2000) and Bok (Suominen et al. 2001) mRNAs were shown to be up- and down-regulated respectively by FSH in vitro, and the $b c l-w$ knockout mouse has elevated germ cell apoptosis following
$14 \mathrm{dpp}$, indicating the potential influence of Bcl-2 family members on the cellular responses in this model.

\section{Identification of genes regulated by FSH in vivo}

Interrogation of a rat gene microarray with RNA from $18 \mathrm{dpp}$ rats in this study identified 60 genes that were regulated by 4 days of FSH suppression in vivo. Twenty percent of these differentially expressed genes have been previously identified as FSH-regulated, predominantly through in vitro methods, a finding which indicates the validity of this model and experimental approach. For example, in an analysis of $20 \mathrm{dpp}$ rat Sertoli cells using the same microarray platform, FSH-responsive mRNAs were identified at 2, 4, 8 and $24 \mathrm{~h}$ of culture (McLean et al. 2002). In accord with the present analysis, that in vitro analysis identified the genes encoding steroidogenic acute regulatory (StAR) protein and endothelin as down- and up- regulated, respectively, in the absence of FSH. FSH has now been identified through both in vitro 
(McLean et al. 2002) and in vivo studies to be one of the wide variety of transcriptional regulators of StAR mRNA synthesis (Gregory \& De Phillip 1998, Manna et al. 2003). Cyclin D2 and androgen binding protein (ABP) are additional Sertoli cell proteins up-regulated by FSH that are required for normal testicular function (Skinner et al. 1989, Danzo 1995, Larriba et al. 1995, Sicinski et al. 1996, Joseph et al. 1997), while protein C inhibitor, also required for spermatogenesis (Uhrin et al. 2000, Odet et al. 2003), appears to be synthesized only in germ cells and Leydig cells (Odet et al. 2003). In vivo confirmation of the negative regulation by FSH of genes encoding insulin-like growth factor binding protein-3 (IGFBP-3) (Smith et al. 1990, Rappaport \& Smith 1995, Khan et al. 2002), HNF-3/ forkhead (Wolfrum et al. 2003), transferring (Kaestner et al. 1998), endothelin-1 (Fantoni et al. 1993, Tripiciano et al. 1999) and cathepsin-L (Penttila et al. 1995, Wright et al. 2003) is presented. Members of the HNF-3/ forkhead transcription factor family are part of a signal transduction cascade from Akt/protein kinase B that regulates transcription of apoptosis-related genes (Wolfrum et al. 2003). HNF-gamma is known to regulate transferrin (Kaestner et al. 1998), a gene that is itself regulated by FSH (Migrenne et al. 2003); we hypothesize that HNF-3 represents an intermediate for FSH regulation of several genes.

The high concordance of the present data with previous reports provides validation of the methodological approach used to identify in vivo targets of FSH regulation, though some differences may be noted. In this study, FSH suppression led to elevated testicular $\mathrm{N}$-cadherin mRNA, but in a previous 2 day in vitro analysis, FSH alone did not affect $\mathrm{N}$-cadherin expression; FSH in combination with testosterone stimulated it (Lampa et al. 1999). This most likely reflects a specific difference between in vitro and in vivo models regarding hormone responses; alternatively, the duration of suppression or addition may underpin the difference between these two results.

In addition, novel candidates for FSH regulation have been uncovered, some of which may be indirectly regulated by altered levels of available FSH or represent bona fide novel FSH-regulated genes. Targets not previously identified in the testis include aminolevulinic acid synthase 2 and melanoma inhibitory activity.

Several categories of encoded gene products within the array of candidate FSH target genes may aid identification of the pathways and processes that underpin the reduction in germ cell survival that was measured after 4 days of treatment with the FSHAb. Most striking are the genes relating to cell cycle regulation and apoptosis (e.g. lamin, cyclin D1, cyclin D2, Scavenger Receptor B1). Products of other FSH target genes comprise or influence the architecture of the seminiferous epithelium (e.g. cadherin, cathepsin L), while others are known to function in signal transduction (e.g. HNF3, MAPKKK, Smad 3, rat retinolbinding protein) and to participate in regulation of hor- monal inputs (StAR and androgen binding protein). However, because the microarray analysis presented in this study addresses a single time point, early and acutely affected FSH gene targets may be undetected. The cellular responses identified in this study (i.e. germ cell apoptosis) would have been initiated before the time point of analysis, so future studies will address this in order to more fully comprehend the pathways through which FSH levels influence Sertoli cell function and germ cell survival.

The limit for microarray signal changes considered to be significant was a 1.5-fold difference between the control and treatment groups. The highest difference detected was 6.57-fold, with several others showing around a 4-fold difference. While this level of change is low in comparison to systems where a single cell type is tested, these data do demonstrate that this approach can identify FSH-regulated genes in a complex cell mixture (i.e. total testis). This is, in fact, comparable to the situation that might be required for analysis of clinical samples, where the small sample size would preclude the use of cell separation methods prior to analysis. The fact that up- and down-regulation of genes is measurable following 4 days of treatment indicates that in conditions where FSH suppression has been long term, FSH target gene expression interrogation may be a useful tool for identifying the basis of pathological change. It is important to note that some alterations in gene expression may be in part attributed to the reduction in testicular weight as a consequence of cell loss. However, we believe the disproportionate change in gene expression (1.5-6 fold) compared with the $22 \%$ reduction in testis weight following FSH suppression indicates that the changes in gene expression are primarily due to specific FSH effects.

In conclusion, the model used in this study has successfully identified distinct developmental responses to FSH in Sertoli and germ cells in the postnatal rat and identified candidate genes that may underpin these responses at 18 dpp. These data illustrate the switch in Sertoli cell function during the first spermatogenic wave, as they cease proliferation and establish a niche for support of germ cell development. In addition, the emerging dependence of germ cells on Sertoli cell-derived products can be explored through identification of FSH-target genes and the pathways in which they function.

\section{Acknowledgements}

We thank Liana Nagley for the preparation of RNA prior to microarray analysis, Sue Hayward for measurement of inhibin levels and Dr Ingrid Sadler-Riggleman for her technical assistance.

\section{Funding}

Supported by the Wellcome Trust Fellow Scheme (\#058479 to S M), and The National Health and Medical 
Research Council of Australia, Program Grants (\#050387 to S J M; \#1147386 to K L L) and Research Fellowship (\#143792 to $\mathrm{K} \mathrm{L} \mathrm{L}$ ). The authors declare that there is no conflict of interest that would prejudice the impartiality of this scientific work.

\section{References}

Andersen OM, Yeung CH, Vorum H, Wellner M, Andreassen TK, Erdmann B, Mueller EC, Herz J, Otto A, Cooper TG \& Willnow TE 2003 Essential role of the apolipoprotein E receptor-2 in sperm development. Journal of Biological Chemistry 278 23989-23995.

Arkblad EL, Egorov M, Shakhparonov M, Romanova L, Polzikov M \& Rydstrom J 2002 Expression of proton-pumping nicotinamide nucleotide transhydrogenase in mouse, human brain and $\mathrm{C}$ elegans. Comparative Biochemistry and Physiology. Part B, Biochemistry and Molecular Biology 133 13-21.

Asuncion L, Fogelgren B, Fong KS, Fong SF, Kim Y \& Csiszar K 2001 A novel human lysyl oxidase-like gene (LOXL4) on chromosome 10q24 has an altered scavenger receptor cysteine rich domain. Matrix Biology 20 487-491.

Baker PJ \& O'Shaughnessy PJ 2001 Role of gonadotrophins in regulating numbers of Leydig and Sertoli cells during fetal and postnatal development in mice. Reproduction 122 227-234.

Beumer TL, Roepers-Gajadien HL, Gademan IS, Kal HB \& de Rooij DG 2000 Involvement of the D-type cyclins in germ cell proliferation and differentiation in the mouse. Biology of Reproduction 63 1893-1898.

Boitani C, Politi MG \& Menna T 1993 Spermatogonial cell proliferation in organ culture of immature rat testis. Biology of Reproduction 48 761-767.

Boitani C, Stefanini M, Fragale A \& Morena AR 1995 Activin stimulates Sertoli cell proliferation in a defined period of rat testis development. Endocrinology 136 5438-5444.

Boussouar F, Mauduit C, Tabone E, Pellerin L, Magistretti PJ \& Benahmed M 2003 Developmental and hormonal regulation of the monocarboxylate transporter 2 (MCT2) expression in the mouse germ cells. Biology of Reproduction 69 1069-1078.

Bravo-Moreno JF, Diaz-Sanchez V, Montoya-Flores JG, Lamoyi E, Saez JC \& Perez-Armendariz EM 2001 Expression of connexin 43 in mouse Leydig, Sertoli and germinal cells at different stages of postnatal development. Anatomical Record 264 13-24.

Brucato S, Bocquet J \& Villers C 2002 Regulation of glypican-1, syndecan-1 and syndecan-4 mRNAs expression by follicle-stimulating hormone, cAMP increase and calcium influx during rat Sertoli cell development. European Journal of Biochemistry $2693461-3469$.

Buemer TL, Roepers-Gajadien HL, Gademan IS, Kal HB \& de Rooij DG 2000 Involvement of the D-type cyclins in germ cell proliferation and differentiation in the mouse. Biology of Reproduction 63 1893-1898.

Buzzard JJ, Wreford NG \& Morrison JR 2002 Marked extension of proliferation of rat Sertoli cells in culture using recombinant human FSH. Reproduction 124 633-634.

Buzzard JJ, Farnworth PG, De Kretser DM, O'Connor AE \& Wreford NG 2003 Proliferative phase Sertoli cells display a developmentally regulated response to activin in vitro. Endocrinology 144 474-483.

Chaudhary J, Sadler-Riggleman I, Ague JM \& Skinner MK 2005 The Helix-Loop-Helix inhibitor of differentiation proteins induce post-mitotic terminally differentiated Sertoli cells to re-enter the cell cycle and proliferate. Biology of Reproduction 72 1205-1217.

Chen JK \& Heckert LL 2001 Dmrt1 expression is regulated by follicle-stimulating hormone and phorbol esters in postnatal Sertoli cells. Endocrinology 142 1167-1178.
Chomczynski P \& Sacchi N 1987 Single-step method of RNA isolation by acid guanidinium thiocyanate-phenol-chloroform extraction. Analytical Biochemistry 162 156-159.

Cooke PS \& Meisami E 1991 Early hypothyroidism in rats causes increased adult testis and reproductive organ size but does not change testosterone levels. Endocrinology 129 237-243.

Danzo BJ 1995 The effects of a gonadotropin-releasing hormone antagonist on androgen-binding protein distribution and other parameters in the adult male rat. Endocrinology 136 4004-4011.

Dufour JM \& Kim KH 1999 Cellular and subcellular localisation of six retinoid receptors in rat testis during postnatal development: identification of potential heterodimeric receptors. Biology of Reproduction 61:1300-1308.

Eisen MB, Spellman PT, Brown PO \& Botstein D 1998 Cluster analysis and display of genome-wide expression patterns PNAS 95 14863-11488.

Ericsson J, Runquist M, Thelin A, Andersson M, Chojnacki T \& Dallner G 1993 Distribution of prenyltransferases in rat tissues. Evidence for a cytosolic all-trans- geranylgeranyl diphosphate synthase. Journal of Biological Chemistry 268 832-838.

Eskild W, Troen G, Blaner WS, Nilsson A \& Hansson V 2000 Evidence for independent control at the mRNA and protein levels of cellular retinol binding protein 1 in rat Sertoli cells. Journal of Reproduction and Fertility 119 101-109.

Fantoni G, Morris PL, Forti G, Vannelli GB, Orlando C, Barni T, Sestini R, Danza G \& Maggi M 1993 Endothelin-1: a new autocrine/paracrine factor in rat testis. American Journal of Physiology - Endocrinology and Metabolism 265 E267-E274.

Fragale A, Puglisi R, Morena AR, Stefanini M \& Boitani C 2001 Age-dependent activin receptor expression pinpoints activin $\mathrm{A}$ as a physiological regulator of rat Sertoli cell proliferation. Molecular Human Reproduction 71 107-114.

Goddard I, Florin A, Mauduit C, Tabone E, Contard P, Bars R, Chuzel F \& Benahmed M 2003 Alteration of lactate production and transport in the adult rat testis exposed in utero to flutamide. Molecular Cell Endocrinology 206 137-146.

Gregory CW \& De Phillip RM 1998 Detection of steroidogenic acute regulatory protein (StAR) in mitochondria of cultured rat Sertoli cells incubated with follicle-stimulating hormone. Biology of Reproduction 58 470-474.

Grima J, Wong CC, Zhu LJ, Zong SD \& Cheng CY 1998 Testin secreted by Sertoli cells is associated with the cell surface, and its expression correlates with the disruption of Sertoli-germ cell junctions but not the inter-Sertoli tight junction. Journal of Biological Chemistry 273 21040-21053.

Henriksen K, Kulmala J, Toppari J, Mehrotra K \& Parvinen M 1996 Stage-specific apoptosis in the rat seminiferous epithelium: quantification of irradiation effects. Journal of Andrology 17 394-402.

Hu J, Shima H \& Nakagawa H 1999 Glial cell line-derived neurotropic factor stimulates Sertoli cell proliferation in the early postnatal period of rat testis development. Endocrinology 140 3416-3421.

Huang HF, Pogach L, Giglio W, Nathan E \& Seebode J 1992 GnRH-A induced arrest of spermiogenesis in rats is associated with altered androgen binding protein distribution in the testis and epididymis. Journal of Andrology 13 153-159.

Ikeda Y \& Terashima T 1999 Expression of reelin, the gene responsible for the reeler mutation, in embryonic development and adulthood in the mouse. Developmental Dynamics 210 157-172.

Jackson VN, Price NT, Carpenter L \& Halestrap AP 1997 Cloning of the monocarboxylate transporter isoform MCT2 from rat testis provides evidence that expression in tissues is species-specific and may involve post-transcriptional regulation. Biochemical Journal 324 447-453.

Joseph DR, O'Brien DA, Sullivan PM, Becchis M, Tsuruta JK \& Petrusz P 1997 Overexpression of androgen-binding protein/sex 
hormone-binding globulin in male transgenic mice: tissue distribution and phenotypic disorders. Biology of Reproduction 56 21-32.

Kabbaj O, Holm C, Vitale C \& Pelletier RM 2001 Expression, activity and subcellular localization of testicular hormone-sensitive lipase during postnatal development in the guinea pig. Biology of Reproduction 65 601-612

Kaestner KH, Hiemisch H \& Schutz G 1998 Targeted disruption of the gene encoding hepatocyte nuclear factor 3 gamma results in reduced transcription of hepatocyte-specific genes. Molecular Cell Biology 18 4245-4251.

von der Kammer H, Hanes J, Klaudiny J \& Scheit KH 1994 A human amyloid precursor-like protein is highly homologous to a mouse sequence-specific DNA-binding protein. DNA Cell Biology 13 1137-1143.

Kastner P, Mark M, Leid M, Gansmuller A, Chin W, Grondona JM, Decimo D, Krezel W, Dierich A \& Chambon P 1996 Abnormal spermatogenesis in RXR beta mutant mice. Genes and Development 10 80-92.

Kato K, Shinohara H, Kurobe N, Inaguma Y, Shimizu K \& Ohshima K 1991 Tissue distribution and developmental profiles of immunoreactive alpha $\mathrm{B}$ crystallin in the rat determined with a sensitive immunoassay system. Biochimica et Biophysica Acta 1074 201-208.

Kawasaki Y, Nakagawa A, Nagaosa K, Shiratsuchi A \& Nakanishi Y 2002 Phosphatidylserine binding of class B scavenger receptor type I, a phagocytosis receptor of testicular Sertoli cells. Journal of Biological Chemistry 277 27559-27566.

Kezele PR, Ague JM, Nilsson E \& Skinner MK 2002 Alterations in the ovarian transcriptome during primordial follicle assembly and development. Biology of Reproduction 72 241-255.

Khan SA, Ndjountche L, Pratchard L, Spicer LJ \& Davis JS 2002 Follicle-stimulating hormone amplifies insulin-like growth factor I-mediated activation of AKT/protein kinase B signaling in immature rat Sertoli cells. Endocrinology 143 2259-2267.

Kirby JD, Jetton AE, Cooke PS, Hess RA, Bunick D, Ackland JF, Turek FW \& Schwartz NB 1992 Developmental hormonal profiles accompanying the neonatal hypothyroidism-induced increase in adult testicular size and sperm production in the rat. Endocrinology 131 559-565.

Lampa J, Hoogerbrugge JW, Baarends WM, Stanton PG, Perryman KJ, Grootegoed JA \& Robertson DM 1999 Follicle-stimulating hormone and testosterone stimulation of immature and mature Sertoli cells in vitro: inhibin and $\mathrm{N}$-cadherin levels and round spermatid binding. Journal of Andrology 20 399-406.

Larriba S, Esteban C, Toran N, Gerard A, Audi L, Gerard H \& Reventos J 1995 Androgen binding protein is tissue-specifically expressed and biologically active in transgenic mice. Journal of Steroid Biochemistry and Molecular Biology 53 573-578.

Li S, Moore CL, Dobretsova A \& Wight PA 2002 Myelin proteolipid protein (Plp) intron 1 DNA is required to temporally regulate Plp gene expression in the brain. Journal of Neurochemistry $\mathbf{8 3}$ 193-201.

Lui WY, Mruk D, Lee WM \& Cheng CY 2003 Sertoli cell tight junction dynamics: their regulation during spermatogenesis. Biology of Reproduction 68 1087-1097.

Machiels BM, Ramaekers FC, Kuijpers HJ, Groenewoud JS, Oosterhuis JW \& Looijenga LH 1997 Nuclear lamin expression in normal testis and testicular germ cell tumours of adolescents and adults. Journal of Pathology 182 197-204.

Maki JM, Tikkanen H \& Kivirikko KI 2001 Cloning and characterization of a fifth human lysyl oxidase isoenzyme: the third member of the lysyl oxidase-related subfamily with four scavenger receptor cysteine-rich domains. Matrix Biology 20 493-496.

Manna P, Wang X-J \& Stocco DM 2003 Involvement of multiple transcription factors in the regulation of steroidogenic acute regulatory protein gene expression. Steroids 68 1125-1134.
Mbikay M, Tadros H, Ishida N, Lerner CP, De Lamirande E, Chen A, El-Alfy M, Clermont Y, Seidah NG, Chretien M, Gagnon C \& Simpson EM 1997 Impaired fertility in mice deficient for the testicular germ-cell protease PC4. PNAS 94 6842-6846.

McChlery SM \& Clarke SC 2003 The use of hydrolysis and hairpin probes in real-time PCR Molecular Biotechnology 25 267-274.

McLachlan RI, Wreford NG, De Kretser DM \& Robertson DM 1995 The effects of recombinant follicle-stimulating hormone on the restoration of spermatogenesis in the gonadotropin-releasing hormone-immunized adult rat. Endocrinology 136 4035-4043.

McLachlan RI, Wreford NG, Meachem SJ, De Kretser DM \& Robertson DM 1994 Effects of testosterone on spermatogenic cell populations in the adult rat. Biology of Reproduction 51 945-955.

McLean DJ, Friel PJ, Pouchnik D \& Griswold MD 2002 Oligonucleotide microarray analysis of gene expression in follicle-stimulating hormone-treated rat Sertoli cells. Molecular Endocrinology 16 2780-2792.

Meachem SJ, McLachlan RI, de Kretser DM, Robertson DM \& Wreford NG 1996 Neonatal exposure of rats to recombinant human follicle-stimulating hormone increases adult Sertoli and spermatogenic cell numbers. Biology of Reproduction 54 36-44.

Meachem SJ, Wreford NG, Stanton PG, Robertson DM \& McLachlan RI 1998 Follicle-stimulating hormone is required for the initial phase of spermatogenic restoration in adult rats following gonadotrophin suppression. Journal of Andrology 19 725-735.

Meachem SJ, McLachlan RI, Stanton PG, Robertson DM \& Wreford NG 1999 FSH immunoneutralization acutely impairs spermatogonial development in normal adult rats. Journal of Andrology 20 756-762.

Meehan T, Schlatt S, O'Bryan MK, de Kretser DM \& Loveland KL 2000 Regulation of germ cell and Sertoli cell development by activin, follistatin and FSH. Developmental Biology 220 225-237.

Meehan T, Loveland KL, de Kretser D, Cory S \& Print CG 2001 Developmental regulation of the bcl-2 family during spermatogenesis: Insights into the sterility of bcl-w-/- male mice. Cell Death and Differentiation 8 225-233.

Meng X, Lindahl M, Hyvonen ME, Parvinen M, de Rooij DG, Hess MW, Raatikainen-Ahokas A, Sainio K, Rauvala H, Lakso M, Pichel JG, Westphal H, Saarma M \& Sariola H 2000 Regulation of cell fate decision of undifferentiated spermatogonia by GDNF. Science 287 1489-1493.

Migrenne S, Racine C, Guillou F \& Habert R 2003 Pituitary hormones inhibit the function and differentiation of fetal Sertoli cells. Endocrinology 144 2617-2622.

Monaco L, Foulkes NS \& Sassone-Corsi P 1995 Pituitary follicle-stimulating hormone (FSH) induces CREM gene expression in Sertoli cells: involvement in long-term desensitization of the FSH receptor. PNAS 92 10673-10677.

Mori T, Guo MW, Sato E, Baba T, Takasaki S \& Mori E 2000 Molecular and immunological approaches to mammalian fertilization. Journal of Reproductive Immunology 47 139-158.

Munsie M, Schlatt S, deKretser DM \& Loveland KL 1997 Expression of stem cell factor in the postnatal rat testis. Molecular Reproduction and Development 47 19-25.

Nozaki H, Matsuzawa T, Nakamura T, Arai I \& Urashima T 2003 Are there two forms of beta 2-N-acetylglucosaminyltransferase I in rat testicular and epididymal fluids? Biochimica et Biophysica Acta 1649 140-145.

O’Donnell L, McLachlan RI, Wreford NG \& Robertson DM 1994 Testosterone promotes the conversion of round spermatids between stages VII and VIII of the rat spermatogenic cycle. Endocrinology $1352608-2614$.

Odet F, Guyot R, Leduque P \& Le Magueresse-Battistoni B 2003 Evidence for Similar Expression of Protein C Inhibitor and the Urokinase-Type Plasminogen Activator System during Mouse Testis Development. Endocrinology 145 1481-1489. 
Orth JM 1984 The role of follicle-stimulating hormone in controlling Sertoli cell proliferation in testes of foetal rats. Endocrinology 115 $1248-1255$.

Orth JM, Gunsalus GL \& Lamperti AA 1988 Evidence from Sertoli cell-depleted rats indicates that spermatid number in adults depends on numbers of Sertoli cells produced during perinatal development. Endocrinology 122 787-794.

Orth JM, Jester WF, Li LH \& Laslett AL 2000 Gonocyte-Sertoli cell interactions during development of the neonatal rodent testis. Current Topics in Developmental Biology 50 103-124.

Orwig KE, Ryu BY, Avarbock MR \& Brinster RL 2002 Male germ-line stem cell potential is predicted by morphology of cells in neonatal rat testes. PNAS 99 11706-11711.

O'Shaughnessy PJ, Willerton L \& Baker PJ 2002 Changes in Leydig cell gene expression during development in the mouse. Biology of Reproduction 66 966-975.

Packer AI, Besmer P \& Bachvarova RF 1995 Kit ligand mediates survival of type A spermatogonia and dividing spermatocytes in postnatal mouse testes. Molecular Reproduction and Development 42 303-310.

Pellegrini M, Grimaldi P, Rossi P, Geremia R \& Dolci S 2003 Developmental expression of BMP4/ALK3/SMAD5 signaling pathway in the mouse testis: a potential role of BMP4 in spermatogonia differentiation. Journal of Cell Science 116 3363-3372.

Penttila TL, Hakovirta H, Mali P, Wright WW \& Parvinen M 1995 Follicle-stimulating hormone regulates the expression of cyclic protein-2/cathepsin L messenger ribonucleic acid in rat Sertoli cells in a stage-specific manner. Molecular and Cellular Endocrinology 113 175-181.

Petersen C, Boitani C, Froysa B \& Soder O 2001 Transforming growth factor-alpha stimulates proliferation of rat Sertoli cells. Molecular and Cellular Endocrinology 181 221-227.

Petersen C, Boitani C, Froysa B \& Soder O 2002 Interleukin-1 is a potent growth factor for immature rat sertoli cells. Molecular and Cellular Endocrinology 186 37-47.

Rappaport MS \& Smith EP 1995 Insulin-like growth factor (IGF) binding protein 3 in the rat testis: follicle-stimulating hormone dependence of mRNA expression and inhibition of IGF-I action on cultured Sertoli cells. Biology of Reproduction 52 419-425.

Raymond CS, Murphy MW, O'Sullivan MG, Bardwell VJ \& Zarkower D 2000 Dmrt1, a gene related to worm and fly sexual regulators is required for mammalian testis differentiation. Genes and Development 14 2587-2595.

Reaven E, Zhan L, Nomoto A, Leers-Sucheta S \& Azhar S 2000 Expression and microvillar localization of scavenger receptor class $\mathrm{B}$, type I (SR-BI) and selective cholesteryl ester uptake in Leydig cells from rat testis. Journal of Lipid Research 41 343-356.

Robertson DM, Hayward S, Irby D, Jacobsen J, Clarke L, McLachlan RI \& de Kretser DM 1988 Radioimmunoassay of rat serum inhibin: changes after PMSG stimulation and gonadectomy. Molecular Cellular Endocrinology 58 1-8.

Robertson DM, Giacometti, M, Foulds L, Lahnstein J, Goss NH, Hearn MTW \& de Kretser DM 1989 Isolation of inhibin alpha-subunit precursor proteins from bovine follicular fluid. Endocrinology 125 2141-2149.

de Rooij DG 1998 Stem cells in testis. International Journal of Experimental Pathology 79 67-80.

Rossi P, Dolci S, Albanesi C, Grimaldi P, Ricca R \& Geremia R 1993 Follicle-stimulating hormone induction of steel factor (SLF) mRNA in mouse Sertoli cells and stimulation of DNA synthesis in spermatogonia by soluble SLF. Developmental Biology 155 68-74.

Russell LD, Alger LE \& Nequin LG 1987 Hormonal control of pubertal spermatogenesis. Endocrinology 120 1615-1632.

Russell LD, Ettlin RA, Sinha Hikim AP \& Clegg ED 1990 Histological and histopathological evaluation of the testis. Ed. LD Russell. Clearwater, Florida: Cache River Press.
Sadate-Ngatchou PI, Pouchnik DJ \& Griswold MD 2004 Identification of testosterone-regulated genes in testes of hypogonadal mice using oligonucleotide microarray Molecular Endocrinology 18 422-433.

Schinkel AH \& Jonker JW 2003 Mammalian drug efflux transporters of the ATP binding cassette (ABC) family: an overview. Advanced Drug Delivery Reviews 55 3-29.

Schlatt S, Zhengwei Y, Meehan T, de Kretser DM \& Loveland KL 1999 Application of morphometric techniques to postnatal rat testes in organ culture: insights into testis growth. Cell and Tissue Research 298 335-343.

Shetty J, Marathe GK \& Dighe RR 1996 Specific immunoneutralization of FSH leads to apoptotic cell death of the pachytene spermatocytes and spermatogonial cells in the rat. Endocrinology 137 2179-2182.

Shima JE, McLean DJ, McCarrey JR \& Griswold MD 2004 The murine testicular transcriptome: Characterizing gene expression in the testis during the Progression of spermatogenesis. Biology of Reproduction 71 319-330.

Sicinski P, Donaher JL, Geng Y, Parker SB, Gardner H, Park MY, Robker RL, Richards JS, McGinnis LK, Biggers JD, Eppig JJ, Bronson RT, Elledge SJ \& Weinberg RA 1996 Cyclin D2 is an FSH-responsive gene involved in gonadal cell proliferation and oncogenesis. Nature 384 470-474.

Simorangkir DR, Wreford NG \& de Kretser DM 1997 Impaired germ cell development in the testes of immature rat with neonatal hypothyroidism. Journal of Andrology 18 186-193.

Skinner MK, Schlitz SM \& Anthony CT 1989 Regulation of Sertoli cell differentiated function: testicular transferrin and androgen-binding protein expression. Endocrinology 124 3015-3024.

Smith EP, Dickson BA \& Chernausek SD 1990 Insulin-like growth factor binding protein-3 secretion from cultured rat Sertoli cells: dual regulation by follicle stimulating hormone and insulin-like growth factor-I. Endocrinology 127 2744-2751.

Sommersberg B, Bulling A, Salzer U, Frohlich U, Garfield RE, Amsterdam A \& Mayerhofer A 2000 Gap junction communication and connexin 43 gene expression in a rat granulose cell line: regulation by follicle-stimulating hormone. Biology of Reproduction 63 1661-1668.

Strothmann K, Simoni M, Mathur P, Siakhamary S, Nieschlag E \& Gromoll J 2004 Gene expression profiling of mouse Sertoli cell lines. Cell Tissue Research 315 249-257.

Suominen JS, Yan W, Toppari J \& Kaipia A 2001 The expression and regulation of Bcl-2-related ovarian killer (Bok) mRNA in the developing and adult rat testis. European Journal of Endocrinology 145 771-778.

Swinnen JV, Tsikalas KE \& Conti M 1991 Properties and hormonal regulation of two structurally related cAMP phosphodiesterases from the rat Sertoli cell. The Journal of Biological Chemistry 266 18370-18377.

Tadokoro Y, Yomogida K, Ohta H, Tohda A \& Nishimune Y 2002 Homeostatic regulation of germinal stem cell proliferation by the GDNF/FSH pathway. Mechanisms of Development 113 29-39.

Tapanainen JS, Tilly JL, Vihko KK \& Hsueh AJ 1993 Hormonal control of apoptotic cell death in the testis: gonadotropins and androgens as testicular cell survival factors. Molecular Endocrinology 76 43-50.

Tripiciano A, Peluso C, Morena AR, Palombi F, Stefanini M, Ziparo E, Yanagisawa M \& Filippini A 1999 Cyclic expression of endothelin-converting enzyme-1 mediates the functional regulation of seminiferous tubule contraction. Journal of Cell Biology 145 $1027-1038$.

Uhrin P, Dewerchin M, Hilpert M, Chrenek P, Schofer C, Zechmeister-Machhart M, Kronke G, Vales A, Carmeliet P, Binder BR \& Geiger M 2000 Disruption of the protein C inhibitor gene results in impaired spermatogenesis and male infertility. Journal of Clinical Investigation 106 1531-1539. 
Ungefroren H, Ergun S, Krull NB \& Holstein AF 1995 Expression of the small proteoglycans biglycan and decorin in the adult human testis. Biology of Reproduction 52 1095-1105.

Van Haaster LH, De Jong FH, Docter R \& de Rooij DG 1992 The effect of hypothyroidism on Sertoli cell proliferation and differentiation and hormone levels during testicular development in the rat. Endocrinology 131 1574-1576.

Walker WH, Sanborn BM \& Habener JF 1994 An isoform of transcription factor CREM expressed during spermatogenesis lacks the phosphorylation domain and represses CAMP-induced transcription. PNAS 91 12423-12427.

West AP, Sharpe RM \& Saunders PT 1994 Differential regulation of cyclic adenosine $3^{\prime}, 5^{\prime}$-monophosphate (cAMP) response element-binding protein and cAMP response element modulator messenger ribonucleic acid transcripts by follicle-stimulating hormone and androgen in the adult rat testis. Biology of Reproduction 50 869-881.

Wolfrum C, Besser D, Luca E \& Stoffel M 2003 Insulin regulates the activity of forkhead transcription factor Hnf-3 beta/Foxa-2 by Akt-mediated phosphorylation and nuclear/cytosolic localization. PNAS 100 11624-11629.

Wolgemuth DJ, Besset V, Liu D, Zhang Q \& Rhee K 1998 Role of cell-cycle genes in the regulation of mammalian meiosis. In Germ Cell Development, Division, Disruption and Death, pp 49-60. Ed Zirkin B. New York: Springer-Verlag.

Wreford NG 1995 Theory and practice of stereological techniques applied to the estimation of cell number and nuclear volume in the testis. Microscopy Research and Technique 32 423-436.
Wright WW, Smith L, Kerr C \& Charron M 2003 Mice that express enzymatically inactive cathepsin L exhibit abnormal spermatogenesis. Biology of Reproduction 68 680-687.

Xu J, Beyer AR, Walker WH \& McGee EA 2003 Developmental and stage-specific expression of Smad2 and Smad3 in rat testis. Journal of Andrology 24 192-200.

Yan W, Kero J, Suominen J \& Toppari J 2001 Differential expression and regulation of the retinoblastoma family of proteins during testicular development and spermatogenesis: roles in the control of germ cell proliferation, differentiation and apoptosis. Oncogenetics 20 1343-1356.

Yan W, Suominen J, Samson M, Jegou B \& Toppari J 2000 Involvement of $\mathrm{Bcl}-2$ family proteins in germ cell apoptosis during testicular development in the rat and pro-survival effect of stem cell factor on germ cells in vitro. Molecular and Cellular Endocrinology 165 $115-129$.

Yomogida K, Yagura Y, Tadokoro Y \& Nishimune Y 2003 Dramatic Expansion of Germinal Stem Cells by Ectopically- Expressed Human Glial Cell Line-Derived Neurotrophic Factor in Mouse Sertoli Cells. Biology of Reproduction 69 1303-1307.

Yoshinaga K, Nishikawa S, Ogawa M, Hayashi S, Kunisada T, Fujimoto T \& Nishikawa S 1991 Role of c-kit in mouse spermatogenesis: identification of spermatogonia as a specific site of c-kit expression and function. Development 113 (Suppl) 689-699.

Received 16 May 2005

Accepted 27 June 2005 